\title{
THE TRANSITION TO THE KNOWLEDGE ECONOMY, LABOUR MARKET INSTITUTIONS, AND INCOME INEQUALITY IN ADVANCED DEMOCRACIES
}

\author{
By DAVID HOPE and ANGELO MARTELLI*
}

\begin{abstract}
The transition from Fordism to the knowledge economy in the advanced democracies was underpinned by the information and communications technology (ICT) revolution. The introduction and rapid diffusion of ICT pushed up wages for college-educated workers with complementary skills and allowed top managers and CEOs to reap greater rewards for their talents. Despite these common pressures, income inequality did not rise to the same extent everywhere; the Anglo-Saxon countries stand out as being particularly unequal. To shed new light on this puzzle, we carry out a panel data analysis of 18 OECD countries between 1970 and 2007. The analysis stands apart from the existing empirical literature by taking a comparative perspective. We look at the extent to which the relationship between the knowledge economy and income inequality is influenced by national labour market institutions. We find that the expansion of knowledge employment is positively associated with both the 90-10 wage ratio and the income share of the top $1 \%$, but that these effects are mitigated by the presence of strong labour market institutions, such as coordinated wage bargaining, strict employment protection legislation, high union density, and high collective bargaining coverage. The study provides robust evidence against the argument that industrial relations systems are no longer important safeguards of wage solidarity in the knowledge economy.
\end{abstract}

Keywords: knowledge economy, income inequality, labour market institutions, industrial relations systems, technological change

\footnotetext{
We would like to give special thanks to Anthony Roberts and Roy Kwon for extensive comments on an earlier version of this article and for sharing their data. We would also like to thank the three anonymous reviewers, as well as Kathleen Thelen, Peter A. Hall, Waltraud Schelkle, Bob Hancké, Orkun Saka, Francesco Amodio, Andrea Garnero, and Niccolo Durazzi, for their detailed and insightful comments. We are also grateful to participants at presentations at the European Institute at the LSE, the Department of Political Economy at King's College London, the European Department at the IMF, the IZA-World Bank-NJD Jobs and Development Conference 2018, and APSA 2018 for their feedback on this research.

Replication data for this article is available at Hope and Martelli 2018a.
} 


\section{INTRODUCTION}

The last forty years has seen a pervasive rise in income inequality across the advanced democracies of Western Europe, North America and the Asia-Pacific region, ${ }^{1}$ especially at the very top of the income distribution. ${ }^{2}$ This occurred alongside major structural change, which saw these economies transition from Fordism - an economic system built around the mass production and mass consumption of standardized consumer goods - to the knowledge economy, where service sectors dominate economic activity and human capital is central to economic prosperity. ${ }^{3}$

The two phenomena are intimately linked. The information and communications technology (ICT) revolution that underpinned the transition to the knowledge economy increased the demand for college-educated workers with complementary skills, which led to a rise in the wage premia for more educated workers. ${ }^{4}$ The effects on wage dispersion were further compounded by the increasing automation of occupations focusing on routine tasks. ${ }^{5}$ The ICT revolution and globalization also allowed top managers, CEOs, and entrepreneurs to apply their talents to a much wider pool of resources and to reach a substantially larger audience than possible in previous generations. The rapidly rising compensation of the top $1 \%$ in the knowledge economy therefore reflects both the increasing complexity of their work and their enhanced ability to reap the rewards of their talents. ${ }^{6}$

\footnotetext{
${ }^{1}$ Kenworthy and Pontusson 2005; OECD 2011; OECD 2015.

2 Alvaredo et al. 2013; Atkinson, Piketty, and Saez 2011; Piketty 2014.

3 Iversen and Soskice 2015; Wren 2013.

4 Katz and Autor 1999; Goldin and Katz 2008; Acemoglu and Autor 2011.

5 Autor and Dorn 2013; Autor, Katz, and Kearney 2006; Autor, Levy, and Murnane 2003; Goos and Manning 2007; Goos, Manning, and Salomons 2009, 2014; Michaels, Natraj, and Van Reenen 2014.

6 Brynjolfsson and McAfee 2014; Mankiw 2013; Kaplan and Rauh 2013.
} 
The transition to the knowledge economy began in earnest after the crisis of Fordism in the 1970s. Figure 1 shows the employment expansion in knowledge-intensive service sectors, such as finance, insurance, business services and telecommunications, between 1970 and $2006 .^{7}$ We can see that the growth of knowledge employment was ubiquitous in the advanced democracies over this period; the average employment expansion was close to 9 percentage points. The rise of the knowledge economy is clearly demonstrated by this substantial shift in economic structure away from traditional industries and towards ICT-intensive service sectors. $^{8}$

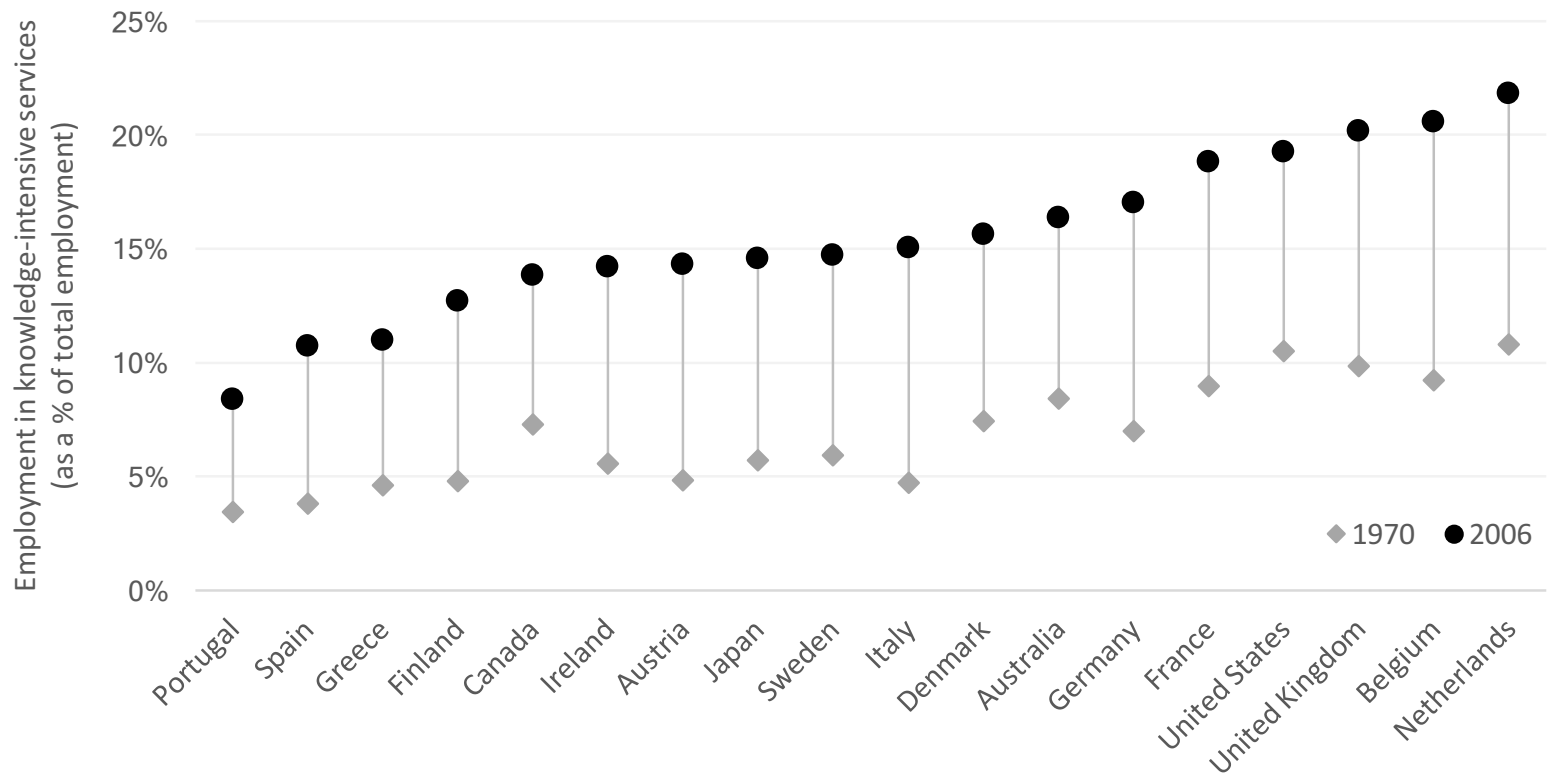

FIGURE 1

THE EXPANSION OF EMPLOYMENT IN KNOWLEDGE-INTENSIVE SERVICES IN ADVANCED DEMOCRACIES BETWEEN 1970 AND 2006

Note: Knowledge-intensive services combines three sectors: post and telecommunications; financial intermediation; and renting of machinery and equipment and other business activities.

Source: EU KLEMS Growth and Productivity Accounts: November 2009 Release, updated March 2011; O'Mahony and Timmer (2009).

\footnotetext{
7 See Section III for a detailed explanation of our measure of knowledge-intensive services.

8 See also, Wren 2013.
} 
While the transition to the knowledge economy has put upward pressure on inequality in all the advanced democracies, we have observed striking differences in the inequality trajectories of different economies. When looking at the evolution of two widely-used measures of income inequality - the income share of the top $1 \%$ and the $90-10$ wage ratio - it is clear that inequality has grown more rapidly in the English-speaking countries than in the continental and northern European economies. ${ }^{9}$

The UK and the US particularly stand out. The top $1 \%$ income share was $7 \%$ in the UK in 1970 , but had risen to $15 \%$ by 2006 . The US saw an even more striking change, with the share rising from $11 \%$ to $20 \%$ over the same period. As we might expect, the UK and the US also saw large employment expansions in knowledge-intensive services. The two countries that saw the biggest movement into knowledge-intensive services, however, were the Netherlands and Belgium, where the growth of inequality has been much more subdued. In the Netherlands, for example, the top $1 \%$ income share was under $7 \%$ in 2006 . On top of this, the other continental and northern Europe economies saw equivalent or greater expansions in knowledgeintensive services than the other English-speaking countries (Australia, Canada and Ireland), but experienced substantially smaller upswings in inequality. This leaves us with a clear puzzle: given the common pressures from the transition to the knowledge economy, why has income inequality not risen to the same extent across the advanced democracies?

Despite the wealth of theoretical and empirical evidence on how labour markets and inequality have been affected by technological progress, there are only a few cross-country empirical analyses that estimate the effects of the transition to the knowledge economy on income inequality in the advanced democracies. ${ }^{10}$ These studies use a range of different

\footnotetext{
9 See Figure S1 in the online supplementary materials; Hope and Martelli 2019. See also Atkinson and Piketty 2007; Alvaredo et al. 2013.

10 Huber, Huo, and Stephens 2017; Kwon and Roberts 2015; Kwon 2014; Rohrbach 2009.
} 
measures of the knowledge economy and income inequality, but typically find that the expansion of knowledge-intensive employment is positively associated with income inequality. ${ }^{11}$ This emerging empirical literature has advanced our understanding of the relationship between the knowledge economy and income inequality, but cannot account for why some advanced democracies have managed to simultaneously expand employment in knowledge-intensive services and maintain relatively high wage solidarity across the workforce, while others have not.

The analysis in this paper aims to shed new light on this puzzle by taking a comparative perspective. There is a large body of empirical work in comparative political economy that finds that labour market institutions, such as coordinated wage bargaining, trade unions, and employment protection legislation, help restrain dispersion in the distribution of income. ${ }^{12}$ There has yet to be a cross-country empirical study, however, that investigates whether labour market institutions can diminish the effects of the transition to the knowledge economy on income inequality.

We fill this gap in the literature by carrying out a panel data econometric analysis using an unbalanced dataset that covers 18 OECD countries from 1970 to 2007. We investigate whether the effect of the knowledge economy on income inequality varies across countries with different labour market institutions. The results show that the expansion of employment in knowledge-intensive services increases income inequality, but that this effect is mitigated by the presence of coordinated wage setting, strict employment protection legislation, and high bargaining coverage. While we find that union density mitigates increases in earnings

\footnotetext{
11 The exception to this is Huber, Huo, and Stephens 2017, who find a significant negative effect of knowledgeintensive services on top incomes. This finding and the issues around the measurement of the knowledge economy will be discussed further in Section III.

12 Iversen 1999; Wallerstein 1999; Rueda and Pontusson 2000; Pontusson, Rueda, and Way 2002; Bradley et al. 2003; Koeniger, Leonardi, and Nunziata 2007; Jaumotte and Buitron 2015; Martelli 2017; Huber, Huo, and Stephens 2017.
} 
dispersion as result of the transition to the knowledge economy, it is the only labour market institution that does not also lessen increases in top income shares.

Our results show that industrial relations systems have played a significant part in keeping income inequality in check in continental and northern Europe during the transition to the knowledge economy. The findings complement recent work that emphasizes the role that (often heavily reformulated) industrial relations systems have played in sustaining more egalitarian labour market outcomes in the knowledge economy in Scandinavia. ${ }^{13}$

The results stand in stark contrast, however, to Lucio Baccaro and Chris Howell's argument that due to the common trajectory of liberalization among advanced democracies, industrial relations institutions have a greatly diminished capacity to achieve egalitarian outcomes in the post-Fordist era. ${ }^{14}$ Our findings also call into question the related argument that industrial relations systems have been superseded by redistribution and education spending as the main safeguards against income inequality in the knowledge economy. ${ }^{15}$

\section{THE KNOWLEDGE ECONOMY, LABOUR MARKET INSTITUTIONS, AND INCOME INEQUALITY}

The post-industrial era has been marked by a dramatic increase in income inequality within the advanced democracies. The richest households in society have typically pulled away from the rest, ${ }^{16}$ and incomes have become more dispersed across the spectrum. ${ }^{17}$ Within this general trend, there have also been marked cross-country differences, with the Anglo-Saxon countries

\footnotetext{
13 Thelen 2014; Ibsen and Thelen 2017.

14 Baccaro and Howell 2011; 2017.

15 Iversen and Soskice 2015.

16 Alvaredo et al. 2013; Atkinson, Piketty, and Saez 2011; Piketty 2014.

17 Kenworthy and Pontusson 2005; OECD 2011; OECD 2015.
} 
typically seeing the greatest rises. ${ }^{18}$ Identifying the factors driving national income inequality has risen to the top of the agenda for many scholars and policy makers, especially in the wake of the global financial crisis. A large theoretical and empirical literature across the fields of economics, political science, and sociology, has identified many potential explanations for the changes observed in income inequality in the advanced democracies.

Claudia Goldin and Lawrence Katz suggest that educational investment (i.e. the supply of skills) has not kept pace with technological advancement (i.e. the demand for skills) in the US, which has put upward pressure on the wages of skilled workers. ${ }^{19}$ Evelyn Huber and John Stephens find evidence supporting the Goldin-Katz hypothesis in a wider panel data analysis of OECD economies. ${ }^{20}$ The supply and demand of skills is likely to be less important for explaining the diverging income of the top 1\%, however, as mass systems of higher education have provided a substantial proportion of the workforce with a college education. Facundo Alvaredo, Anthony Atkinson, Thomas Piketty, and Emmanuel Saez instead find that tax policy, changes in the bargaining power of managers and employees, the greater individualisation of pay, and capital income, are more salient for explaining changes in the income share of the top $1 \% .{ }^{21}$ In a panel data study of 16 OECD countries over the entire $20^{\text {th }}$ century, Jesper Roine, Jonas Vlachos, and Daniel Waldenström find that top income shares are boosted by rapid economic growth and financial development, and reined in by banking crises and the progressivity of the tax system. ${ }^{22}$ Turning to an influential political science analysis on the rise of top incomes in the United States, Jacob Hacker and Paul Pierson point to the profound role of government policy in creating the current "winner-take-all" pattern,

\footnotetext{
18 Acemoglu 2003; Atkinson and Piketty 2007; Atkinson, Piketty, and Saez 2011; Lemieux 2011.

19 Goldin and Katz 2007; Goldin and Katz 2008.

20 Huber and Stephens 2014.

21 Alvaredo et al. 2013.

22 Roine, Vlachos, and Waldenström 2009.
} 
and highlight the remarkable ability of the most affluent households and lobbyists representing their interests to shape public policy in their favour. ${ }^{23}$

Financialization - the increasing influence over economic policymaking and economic outcomes of financial markets and financial actors ${ }^{24}$ - has been identified in a number of national and cross-country empirical studies as another important driver of both greater wage disparities and the concentration of income in the most affluent households. ${ }^{25}$ Financialization has both direct and indirect effects on inequality. Workers in the finance sector are typically much better remunerated than the average worker. ${ }^{26}$ The spread of shareholder value maximisation models of corporate governance in the financial and non-financial sector privileges short-term profits and encourages cost cutting and mass layoffs that disproportionately affect ordinary workers. ${ }^{27}$ Relatedly, Ken-Huo Lin and Donald TomaskovicDevey provide strong empirical evidence that the increasing reliance of non-financial firms in the United States on earnings realized through financial channels has led firm surpluses to be split more in favour of managers and owners, which has significantly contributed to rises in earnings dispersion and top executives' share of total compensation. ${ }^{28}$ Financialization can also weaken labour market institutions that act to constrain inequality, such as unions, centralized wage bargaining, and employment protection legislation. ${ }^{29}$ Recent contributions from Thibault Darcillon and Anthony Roberts and Roy Kwon have also found evidence that labour market institutions can effectively moderate the effects of financialization on income inequality. ${ }^{30}$

\footnotetext{
23 Hacker and Pierson 2010; Hacker and Pierson 2011.

24 Palley 2013.

25 Kus 2012; Flaherty 2015; Assa 2012; Godechot 2016.

26 Tomaskovic-Devey and Lin 2011; Philippon and Reshef 2012.

27 Fligstein and Shin 2007; Tomaskovic-Devey and Lin 2011; Kus 2012.

28 Lin and Tomaskovic-Devey 2013.

29 Palley 2013; Darcillon 2015; Meyer 2017.

30 Darcillon 2016; Roberts and Kwon 2017. See also, Kwon, Roberts, and Zingula 2017.
} 
Other scholars have highlighted the rise in international trade liberalizations, finding that trade tariffs reductions led to increased inequality. ${ }^{31}$ Cross-country studies on inequality and globalization have found that measures of trade and capital account integration, such as southern import penetration and outward investment flows, have significant positive effects on within-country inequality, but are less pertinent to explaining cross-country differences. ${ }^{32}$ Although, Cheol-Sung Lee, François Nielsen, and Arthur Alderson find that these globalization effects are mitigated in countries with larger public sectors. ${ }^{33}$

Despite the wide-ranging explanations put forward for changes in income inequality, technological change and labour market institutions remain the two dominant factors in the literature. These two factors are the focus of our paper. In the remainder of the literature review, we look at the direct effects of technological change and labour market institutions on income inequality, before turning to the potential interaction effect between the two factors that is at the heart of our empirical analysis.

\section{THE KNOWLEDGE ECONOMY AND INEQUALITY}

The advanced democracies have undergone a major technologically-driven structural transformation since the 1970s. The common overarching narrative among comparative political economists is that the advanced economies have transitioned from the Fordist manufacturing system of the post-WWII golden age to the knowledge economy of the postindustrial era. ${ }^{34}$ The Fordist system was built on the dual pillars of mass production and mass consumption, and was supported by collective bargaining, a generous welfare state, and

\footnotetext{
31 Milanovic and Squire 2005.

32 Alderson and Nielsen 2002.

33 Lee, Nielsen, and Alderson 2007.

34 See, for example, Thelen 2014; Iversen and Soskice 2015; Ibsen and Thelen 2017.
} 
Keynesian demand management policies. This system collapsed under the weight of short-term factors, such as industrial conflict and oil price shocks, and longer term factors, such as globalization, de-unionization, and technological change. ${ }^{35}$ The knowledge economy that arose in its place is distinct from what went before in a number of ways. Manufacturing has receded in importance and service sectors now dominate economic activity. Complementarities in production between skilled and semi-skilled workers have been replaced by complementarities between skilled workers and new information and communication technologies. These changes have brought about a huge increase in skill and education levels of big segments of the labour force, facilitated through the rapid expansion of higher education. ${ }^{36}$ The welfare state, collective bargaining and labour unions have generally declined in importance over time, but there are still significant and theoretically salient differences in labour market institutions and welfare states among the advanced democracies in the knowledge economy. ${ }^{37}$

Of course, the CPE perspective on structural change glosses over substantive crossnational differences. For example, Fordism was certainly not the same everywhere. ${ }^{38}$ As Torben Iversen and David Soskice concede in their influential paper on distribution and redistribution in the knowledge economy, Fordism "took on more or less skill-intensive forms and economies of scale were important to different degrees". ${ }^{39}$ What is important for the purposes of research into the relationship between the knowledge economy and income inequality, however, is that the advanced democracies economies have faced a similar set of secular trends since the 1970s (e.g. technological change, deindustrialization, and globalization) that have put upward

\footnotetext{
${ }^{35}$ Hope and Soskice 2016.

${ }^{36}$ Iversen and Soskice 2015.

37 Pontusson 2005; Schneider and Paunescu 2012; Iversen and Soskice 2012; Thelen 2014.

38 This is especially true for the late-developing peripheral Eurozone countries (Greece, Ireland, Portugal and Spain), as will be discussed further in Section III.

39 Iversen and Soskice 2015, 194.
} 
pressure on income inequality through a number of common channels, such as the rising skill premium for highly educated workers, worsening labour market dualization, the expansion of temporary and precarious work, and the shrinking core of unionized production workers. ${ }^{40}$

The information and communication technology (ICT) revolution that underpinned the transition to the knowledge economy has been found to be a key driver behind the upward trend of earnings inequality since the 1980s. Wen-Hao Chen, Michael Förster, and Ana LlenaNozal carry out a cross-national study into the drivers of inequality in OECD countries and find that technological change (measured by ICT intensity, R\&D expenditure, and patents) significantly widens wage dispersion and accounts for more of the within-country variation in inequality than trade or financial factors. ${ }^{41}$ In a complementary panel data study covering 51 countries between 1981 and 2003, Florence Jaumotte, Subir Lall, and Chris Papageorgiou find that technological progress exerts a greater impact than trade or financial globalization on income inequality. ${ }^{42}$

The diffusion of ICT throughout the advanced democracies created a sharp upturn in demand for college-educated workers, because their high-level, general skills are complements in production to ICT. The additional demand for skilled workers that came with these new technologies led to a rise in the relative wages of more educated workers. ${ }^{43}$ The losers from technological change have typically been those workers in the middle of the skill distribution, whose jobs focus on routine tasks that can be easily be replicated by computers or machines. ${ }^{44}$

\footnotetext{
40 Palier and Thelen 2012; Emmenegger et al. 2012; Iversen and Soskice 2015; Ibsen and Thelen 2017.

41 Chen, Förster, and Llena-Nozal 2013.

42 Jaumotte, Lall, and Papageorgiou 2013.

43 Katz and Autor 1999; Goldin and Katz 2008; Acemoglu and Autor 2011.

44 Autor and Dorn 2013; Autor, Katz, and Kearney 2006; Autor, Levy, and Murnane 2003; Goos and Manning 2007; Goos, Manning, and Salomons 2009, 2014; Michaels, Natraj, and Van Reenen 2014.
} 
The knowledge economy also contributed to the rapid rise in the income of the top $1 \%$ during the post-industrial era. Kevin Murphy and Ján Zábojník provide a market-based explanation for the explosion of CEO pay in the knowledge economy, arguing that the skills needed to manage a modern corporation are much more focused on general, transferable skills (e.g. management, economics, accounting, computing etc.) than the firm-specific knowledge that was important in the pre-digital era, and this has created a highly competitive global market for the best CEOs. ${ }^{45}$ In a study of over 2,500 publicly traded firms, Kim and Brynjolfsson find that information technology intensity strongly predicts CEO pay. ${ }^{46}$ Building on Garicano and Rossi-Hanberg's argument, ${ }^{47}$ they argue that IT increases the 'effective size' of the firm that the CEO runs, due to the greater information available for decision-making, the enhanced ability for the CEO's decisions to be passed through the business hierarchy, and greater scope for monitoring and enforcing those decisions.

The integration of capital and goods markets that came with ICT and globalization also allows highly-talented managers, CEOs and entrepreneurs to operate in more markets and reach more customers. The rapidly rising compensation of the top $1 \%$ in the knowledge economy therefore reflects both their superior ability to reap the rewards of their talents and the greater complexity of their roles. ${ }^{48}$ An aspect of the knowledge economy, particularly in new digital technologies, that reinforces this dynamic is the existence of large networks effects, whereby the value of a product rises the greater number of users it has (e.g. social media platforms). Network effects often lead to the creation of winner-take-all or winner-take-most markets, where the first mover gets a disproportionate amount of the returns in an industry. ${ }^{49}$

\footnotetext{
45 Murphy and Zábojník 2004.

${ }^{46}$ Kim and Brynjolfsson 2009.

47 Garicano and Rossi-Hansberg 2006.

48 Brynjolfsson and McAfee 2014; Mankiw 2013; Kaplan and Rauh 2013.

49 Brynjolfsson and McAfee 2014.
} 
This also ties into recent work finding that trends in the personal and functional distributions of income in the United States are being increasingly driven by greater earnings dispersion among firms, with 'superstar' firms in knowledge-intensive industries, such as finance, technology, and business services, making higher profits and paying considerably higher wages than less productive firms within their own (and other) industries. ${ }^{50}$

\section{LABOUR MARKET INSTITUTIONS AND INEQUALITY}

A wealth of empirical evidence has emerged that institutional factors, such as wage coordination, trade union density, collective bargaining coverage, and employment protection legislation, shape patterns of income inequality in the advanced democracies. The inequality constraining effects of labour market institutions have been found in numerous time-series ${ }^{51}$ and cross-national panel studies. ${ }^{52}$ In a simple model in which unions bargain with employers over the wage, "if labour market institutions improve the outside option more for unskilled than for skilled workers, this will strengthen their bargaining position and tend to compress the skill wage differential". ${ }^{53}$ The theoretical channel could be argued to apply to the full range of labour market institutions, but as Winfried Koeniger, Marco Leonardi, and Luca Nunziata freely admit, labour market institutions are complex and multifaceted, and are also likely to affect wage differentials through many other channels. ${ }^{54}$ The remainder of this subsection will therefore address the literature on each labour market institution in turn.

\footnotetext{
50 Autor et al. 2017a, 2017b; Barth et al. 2016; Song et al. 2015.

51 Mosher 2007; Kristal and Cohen 2007; Western and Rosenfeld 2011; Kristal and Cohen 2017.

52 Brady, Baker, and Finnigan 2013; Brady and Leicht 2008; Kenworthy and Pontusson 2005; Pontusson, Rueda, and Way 2002; Wallerstein 1999; Koeniger, Leonardi, and Nunziata 2007; Iversen 1999.

53 Koeniger, Leonardi, and Nunziata 2007, 341.

54 Koeniger, Leonardi, and Nunziata 2007.
} 
In an empirical study of OECD countries, Wallerstein finds that "the more wage and salaries are set in a centralized manner, the more egalitarian the distribution of wages and salaries". ${ }^{556}$ The three theoretical channels that Wallerstein identifies as explaining this relationship are the economic explanation (i.e. wage differentials in decentralized wage-setting systems are inefficient), the political explanation (i.e. compressed wages in centralized wagesetting systems reflect the preferences of the median wage-earner), and the norms explanation (i.e. centralized bargaining influences norms around fairness). ${ }^{57}$ The importance of wage coordination is also emphasized in other empirical studies. Francine Blau and Lawrence Kahn's much cited analysis finds that decentralized wage-setting systems in the US provide the most persuasive explanation for the higher level of wage inequality in the US than in the other OECD countries. ${ }^{58}$ Focusing on Israel, Tali Kristal and Yinon Cohen find that decentralization explains a significant part of the escalating earnings inequality since 1970, with the reduction in the use of extension orders and the spread of local agreements highlighted as particularly salient factors. ${ }^{59}$

There is substantial evidence that labour unions, in their role as both wage bargainers and political actors, influence class-based inequity in politics and public policy, and therefore reduce economic disparities. ${ }^{60}$ David Card, Thomas Lemieux, and Craig Riddell find that in Canada, the UK, and the US, unions have an equalizing effect on the dispersion of male wages across skill groups, as they flatten the wages of union workers - who are concentrated in the middle of the income distribution - relative to non-union workers, as well as compressing the

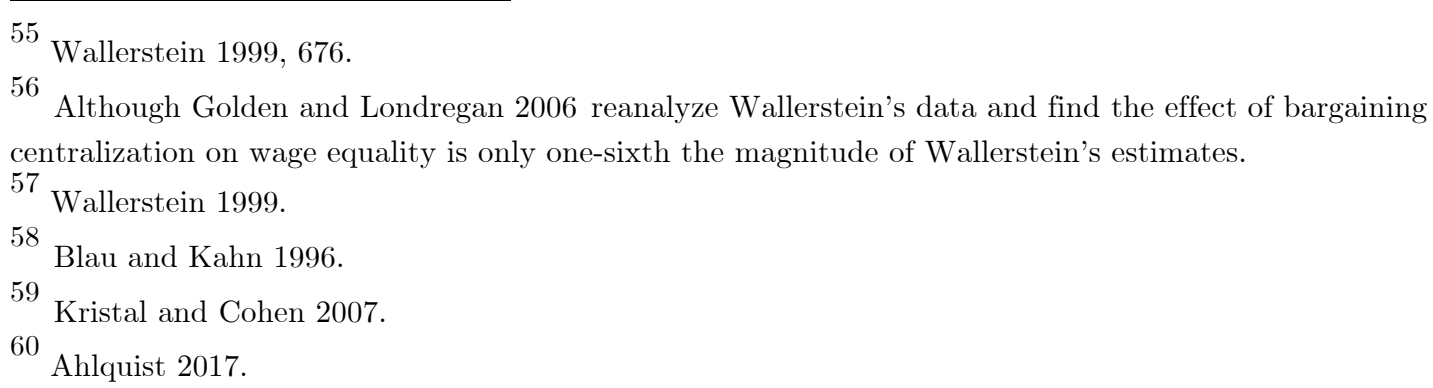


wages of union members. ${ }^{61}$ Card finds similar effects in a micro data study on the United States, with union decline accounting for $15-20 \%$ of the rise in male income inequality between the early 1970s and the early 1990s. ${ }^{62}$ It is also argued that unions help to institutionalize norms of equity. ${ }^{63}$ Bruce Western and Jake Rosenfeld present evidence in line with this theory, showing that non-union wages are less dispersed in highly unionized industries and regions in the United States. ${ }^{64}$

The strength of unions and their bargaining power can be measured in two ways, either through union density (unions members as proportion of wage and salary earners) or bargaining coverage (employees covered by collective wage bargaining agreement as a proportion of wage and salary earners). While the two measures are often closely related, this is not always the case. France, for example, had bargaining coverage of $98 \%$ in 2012, but union density of below $8 \%{ }^{65}$ Looking at both measures therefore provides a fuller picture. Existing cross-country empirical studies predominantly focus on union density, due to its superior data availability. ${ }^{66}$ A notable exception is Stefan Thewissen, Olaf van Vliet, and Chen Wang, who argue that bargaining coverage will be negatively associated with earnings inequality, because wages vary less between workers when more of the workforce are covered by bargaining agreements. ${ }^{67}$ They find strong evidence supporting their hypothesis in an analysis of sectoral earnings inequality in 18 OECD countries. ${ }^{68}$

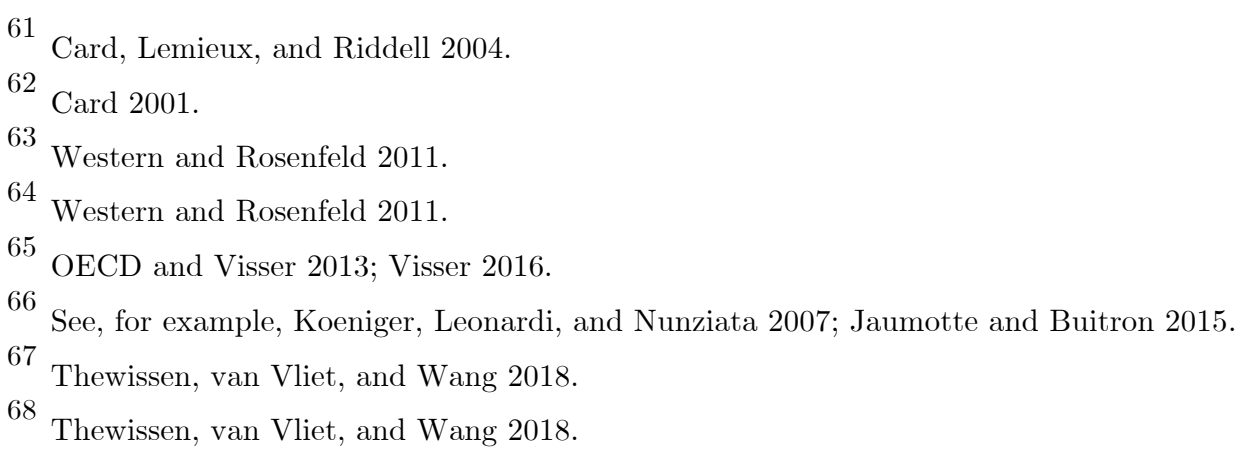


The richest households in the advanced democracies are unlikely to be union members or covered by collective bargaining agreements, but this does not mean their incomes are unaffected by the strength of labour unions. ${ }^{69}$ Unions can serve as an important check on executive compensation by instituting fairness norms, reducing the resources available for high executive pay (through higher worker wages), restraining the use of stock options in CEO pay, and lessening the need for highly paid managers and supervisors (due to greater worker discretion and performance in unionized workplaces). ${ }^{70}$ In fact, there is a strong negative relationship in the United States between union presence and CEO compensation. ${ }^{71}$ Given the major role that executive compensation plays in the income share of the top $1 \%$, it is unsurprising that cross-country studies also consistently find a negative relationship between union density and top $1 \%$ income shares. ${ }^{72}$

As well as industrial relations systems, there is evidence that employment protection legislation (EPL) can influence the distribution of income. Daniele Checchi and Cecilia GarcíaPeñalosa find that OECD countries with stricter employment protection legislation, where workers are much harder to fire, typically have lower levels of household income inequality. ${ }^{73}$ EPL has been argued to reduce wage inequality between skilled and unskilled workers, as the substantial fixed cost component means EPL offers greater protection to unskilled workers. ${ }^{74}$ It has also been shown that EPL is associated with lower use of incentive pay, ${ }^{75}$ which is likely

\footnotetext{
69 Huber, Huo, and Stephens 2017.

70 Huber, Huo, and Stephens 2017; Gomez and Tzioumis 2006; Kristal and Cohen 2017.

71 DiNardo, Hallock, and Pischke 1997; Gomez and Tzioumis 2006; Shin 2014.

72 Scheve and Stasavage 2009; Neal 2013; Jaumotte and Buitron 2015; Huber, Huo, and Stephens 2017.

73 Checchi and García-Peñalosa 2008.

74 Koeniger, Leonardi, and Nunziata 2007; Boeri, Ignacio, and Vincenzo 2012.

75 Bryson et al. 2012.
} 
to reduce income inequality, due to the positive association between the use of incentive pay schemes, such as bonus pay and commissions, and wage inequality. ${ }^{76}$

\section{THE INTERACTION OF LABOUR MARKET INSTITUTIONS AND THE KNOWLEDGE ECONOMY}

The previous two subsections have highlighted the vast literature on the direct effects of the transition to the knowledge economy and labour market institutions on income inequality in advanced democracies. These two dominant explanations for rising income inequality are commonly viewed as distinct and competing in the literature. In fact, several recent contributions have aimed to empirically assess the relative importance of the two channels. ${ }^{77}$ Kristal and Cohen analyse industry-level data from the United States and find that weakening institutions (unions and minimum wages) explain around half of the rise in wage inequality since the late $1960 \mathrm{~s}$, whereas computerization only explains about a quarter. ${ }^{78}$ A time-series study using aggregate data came to the opposite conclusion, with the effect of ICT investment outstripping that of the declining unionization rate. ${ }^{79}$ Looking across the OECD countries using panel data, the OECD finds that institutions are the more important factor. ${ }^{80}$ It is clear that the results of studies weighing up the two explanations are dependent on the empirical approach taken. What all these studies fail to take into account-and one possible source of their lack of consensus - is the potential interaction effects between labour market institutions and the expansion of the knowledge economy.

\footnotetext{
76 Lemieux, MacLeod, and Parent 2009.

77 As discussed further in the introduction to Kristal and Cohen 2015.

78 Kristal and Cohen 2017.

${ }^{79}$ Wolff 2006

80 OECD 2011.
} 
Whether the relationship between the expansion of knowledge-intensive services and income inequality depends on national labour market institutions has received relatively little attention in the literature to date. To the best of our knowledge, there have been no crossnational empirical studies that investigate whether labour market institutions are able to mitigate the inequality-enhancing effects of the transition to the knowledge economy. Despite the lack of panel data analyses into the relationship, the literature has identified several theoretical arguments that provide clear motivation for focusing our study on this interaction.

The divergence of US and continental European wage inequality and the beginnings of the ICT revolution meant the 1990s were a fertile ground for economic theories looking to explain cross-country differences in labour market outcomes. The influential "Krugman hypothesis" suggested that the answer lie in labour market institutions. ${ }^{81}$ While both the US and continental Europe were subject to the same skills-biased technical change, stronger labour market institutions in continental Europe, such as unions and employment protection, meant that these countries were better able to contain wage dispersion, but only at the expense of low-skilled employment. While intuitive and persuasive, the Krugman hypothesis was not adequately supported by the empirical evidence. It implied that employment losses in continental Europe should be concentrated in low-skilled occupations, but on closer inspection, the labour market statistics showed that employment losses were relatively evenly distributed across skills groups. ${ }^{82}$

An alternative theory that better fit the stylized facts was put forward in a series of papers by Daron Acemoglu and Jörn-Steffen Pischke around the turn of the century. ${ }^{83}$ The core of their argument was that human and physical capital investment decisions by firms are

81 Krugman 1994.

82 Nickell and Bell 1996; Nickell and Bell 1995; Krueger and Pischke 1998.

83 Acemoglu and Pischke 1998; Acemoglu and Pischke 1999a; Acemoglu and Pischke 1999b; Acemoglu 2003. 
dependent on labour market institutions. In the face of the expansion of the world technology frontier that occurred with the ICT revolution, countries with institutions that compress wages, such as unions and coordinated wage bargaining, should see relatively more investment in both worker training and technologies complementary to low-skilled labour. In countries where these institutions are absent, investment instead shifts toward technologies complementary to high-skilled workers. These effects occur because technological change provides different investment incentives for firms depending on the extent to which labour market institutions (or other factors) compress the wage structure.

This implies less skills-biased technical change in countries with strong labour market institutions, and consequently, less of a rise in the wage gap between skilled and unskilled workers. Building on the analyses in their previous work, Pischke presents empirical evidence that accords with their theory, showing that on-the-job training and physical capital investments were more focused on high-skilled workers in the US than Europe during the 1980s, when wage inequality dramatically diverged on either side of the Atlantic. ${ }^{84}$ In a complementary empirical analysis, Koeniger and Leonardi compare the effect of capital investment on wage inequality using industry-level data from Germany, with strong labour market institutions, and the US, with flexible labour markets. ${ }^{85}$ They find that capital deepening pushed up wage differentials more than $7 \%$ in US industries during the 1980s, but due to investment being directed more toward unskilled workers, capital deepening actually reduced wage differentials in German industries by 5-7\% over the same period.

More recent work by the sociologist Daniel Oesch and co-authors in the tradition of Acemoglu and Pischke argues that whether technological change leads to upgrading (as seen

\footnotetext{
84 Pischke 2005.

85 Koeniger and Leonardi 2007.
} 
in northern Europe) or polarization (as seen in Britain and the US) depends in part on national labour market institutions and welfare regimes. ${ }^{86}$ Institutions that prop up the wages of lowskilled workers provide an incentive for firms to invest in skills and technologies to enhance the productivity of the interpersonal service workers that are typically located at the bottom of the skill and income distribution in the knowledge economy (for example, by introducing self-service checkouts in supermarkets). ${ }^{87}$ Hence, Oesch sees institutions as mitigating the relationship between the expansion of the knowledge economy and rising income inequality. Caroline Lloyd, Claudia Weinkopf, and Rosemary Batt find further evidence of this type of interaction effect in a multi-country case study of call centre workers in Europe. ${ }^{88}$ Through a series of in-depth interviews and workplace observations, they discover that call centre employees in the United Kingdom, which has few labour market protections and little collective representation, are less skilled, have less complex and diverse roles, and are paid less relative to the median, than call centre employees in Denmark and France.

In research focusing specifically on whether national labour market institutions shape the response of employment structures to technological change in Europe, Angelo Martelli finds that EPL effectively mitigates employment losses in industries and occupations that are susceptible to routinization (the replacement of labour carrying out routine tasks with computers or machines). ${ }^{89}$ In contrast, union density was not found to alleviate the effects of routinization on the employment structure. Martelli also looks at how EPL affects wage inequality, finding that it restricts dispersion in the upper tail of the earnings distribution (90/50), while raising dispersion in the lower tail of the earnings distribution (50/10). He finds

\footnotetext{
86 Oesch and Rodríguez Menés 2011; Oesch 2013; Oesch 2015; Murphy and Oesch 2017. 87 Oesch 2015.

88 Lloyd, Weinkopf, and Batt 2010.

89 Martelli 2017.
} 
that the former effect is larger in magnitude, so EPL both contains the wage effects of routinization and compresses the overall wage distribution (i.e. the 90-10 wage ratio).

Roberts and Kwon look at whether the impact of financialization on income inequality differs across varieties of capitalism. ${ }^{90}$ One of their measures of financialization is the employment share of the finance, insurance and real estate (FIRE) sectors. Finance and insurance are knowledge-intensive industries that make extensive use of ICT, so their results are relevant for our study. They find that financialization increases wage dispersion and top incomes more in liberal market economies (LMEs), such as the Anglo-Saxon countries, than coordinated market economies (CMEs), such as the northern European countries. LMEs have lower employment protection, weaker collective bargaining, and more shareholder orientated corporate governance, which make them more amenable to profit-making strategies that rely on short-termism, cost-cutting (including mass layoffs), and non-production (i.e. financial) activities. $^{91}$

Labour market institutions can also restrain the incomes of the most affluent workers in knowledge-based industries. As we saw earlier in the literature review, top managers and CEOs roles grew more complex with the ICT revolution, which put upward pressure on their compensation. $^{92}$ Knowledge-intensive industries, such as technology and finance, are particularly ICT intensive, and are prone to winner-take-all markets and a disproportionate share of income and profits going to the most productive 'superstar firms' ${ }^{93}$ Hacker and Pierson (alongside many others) argue that labour unions have the organizational and financial resources, as well as the motivation, to rein in the compensation of executives and ensure

\footnotetext{
90 Roberts and Kwon 2017.

91 Roberts and Kwon 2017.

92

Kim and Brynjolfsson 2009; Mankiw 2013; Kaplan and Rauh 2013.

93 Autor et al. 2017a; Autor et al. 2017b; Brynjolfsson and McAfee 2014.
} 
packages are structured in the interests of the firm as a whole and not just management. ${ }^{94}$ It follows that countries with stronger labour market institutions are likely to be better placed to contain the rise in executive compensation from the ICT revolution and the shift of employment into knowledge-intensive industries. Hacker and Pierson also argue that organized labour focuses on the broad concerns of those on modest incomes and can help ensure that public policy does not simply represent the interests of the rich. In the shift to the knowledge economy, one could think of financial deregulation and tax policies as salient political conflicts that had dramatic implications for the distribution of income. ${ }^{95}$

\section{DATA AND MEASURES}

Our empirical analysis uses an unbalanced panel dataset covering 18 OECD countries from 1970 to 2007. The countries included in the sample-Australia, Austria, Belgium, Canada, Denmark, Finland, France, Germany, Greece, Ireland, Italy, Japan, the Netherlands, Portugal, Spain, Sweden, the UK and the US - vary markedly in their industrial relations systems, ${ }^{96}$ and more broadly, in the organization of their political economies. ${ }^{97}$

As alluded to earlier, Fordism did not take the same form in all the advanced democracies in the sample, especially in the late-developing peripheral Eurozone countries. ${ }^{98}$ However, at the start of the sample period in 1970, manufacturing employment was similarly important to the peripheral Eurozone countries as it was in many of the higher-income OECD countries,

\footnotetext{
94 Hacker and Pierson 2010; Hacker and Pierson 2011. See also, Gomez and Tzioumis 2006; Huber, Huo, and Stephens 2017.

95 Hacker and Pierson 2010; Hacker and Pierson 2011.

96 Pontusson 2005.

97 Hall and Soskice 2001; Schneider and Paunescu 2012; Thelen 2014.

98 As Arestis and Paliginis (1995, 267) neatly summarize, the Fordist era in Greece, Ireland, Portugal and Spain was characterized by "a large and inefficient agricultural sector and a late developing industrial sector, partly controlled by multinational capital".
} 
such as Austria, Finland, the Netherlands, and the United States (as shown in Table 1). During the period under analysis, the 18 countries faced the same secular trends (technological change, deindustrialization, and globalization) and without exception saw employment shift out of manufacturing and into (among other sectors) knowledge-intensive services (see Table 1). The combination of common structural changes and cross-country variation in knowledge employment, labour market institutions and income inequality, make these countries a suitable sample for this study. The sample also closely aligns with previous cross-country empirical analyses that estimate the relationship between knowledge employment and income inequality. $^{99}$

99 Rohrbach 2009; Kwon 2014; Kwon and Roberts 2015; Huber, Huo, and Stephens 2017. 
TABLE 1

EMPLOYMENT SHARES IN MANUFACTURING AND KNOWLEDGE-INTENSIVE SERVICES, 1970 \& 2006

\begin{tabular}{lllll}
\hline & \multicolumn{2}{l}{$\begin{array}{l}\text { Employment in manufacturing } \\
\text { (as a \% of total employment) }\end{array}$} & \multicolumn{2}{l}{$\begin{array}{l}\text { Employment in knowledge-intensive } \\
\text { services a }\end{array}$} \\
& 1970 & 2006 & 1970 & 2006 \\
\hline Australia & $26.5 \%$ & $10.2 \%$ & $8.4 \%$ & $16.3 \%$ \\
Austria & $22.3 \%$ & $14.9 \%$ & $4.8 \%$ & $14.3 \%$ \\
Belgium & $30.8 \%$ & $13.9 \%$ & $9.2 \%$ & $20.6 \%$ \\
Canada & $22.1 \%$ & $11.8 \%$ & $7.3 \%$ & $13.8 \%$ \\
Denmark & $25.9 \%$ & $13.8 \%$ & $7.4 \%$ & $15.6 \%$ \\
Finland & $23.0 \%$ & $17.9 \%$ & $4.8 \%$ & $12.7 \%$ \\
France & $25.1 \%$ & $13.0 \%$ & $9.0 \%$ & $18.8 \%$ \\
Germany & $35.3 \%$ & $19.1 \%$ & $7.0 \%$ & $17.0 \%$ \\
Greece & $19.2 \%$ & $13.4 \%$ & $4.6 \%$ & $11.0 \%$ \\
Ireland & $20.9 \%$ & $13.3 \%$ & $5.5 \%$ & $14.2 \%$ \\
Italy & $27.6 \%$ & $20.2 \%$ & $4.7 \%$ & $15.0 \%$ \\
Japan & $26.0 \%$ & $17.4 \%$ & $5.7 \%$ & $14.6 \%$ \\
Netherlands & $23.9 \%$ & $11.0 \%$ & $10.8 \%$ & $21.8 \%$ \\
Portugal & $22.8 \%$ & $17.7 \%$ & $3.4 \%$ & $8.4 \%$ \\
Spain & $22.2 \%$ & $15.6 \%$ & $3.8 \%$ & $10.7 \%$ \\
Sweden & $27.8 \%$ & $16.1 \%$ & $5.9 \%$ & $14.7 \%$ \\
United Kingdom & $31.7 \%$ & $10.9 \%$ & $9.8 \%$ & $20.1 \%$ \\
United States & $21.7 \%$ & $10.0 \%$ & $10.5 \%$ & $19.2 \%$ \\
\hline
\end{tabular}

Note: Knowledge-intensive services comprise three sectors: post and telecommunications; financial intermediation; and renting of machinery and equipment and other business activities.

Source: EU KLEMS Growth and Productivity Accounts: November 2009 Release, updated March 2011; O’Mahony and Timmer (2009).

\section{DEPENDENT VARIABLE}

We use two measures of income inequality as our dependent variables, which allows us to test the effects of our key independent variables on different parts of the income distribution. The first is the income share of the top $1 \%$ from the World Wealth and Income Database. ${ }^{100}$ The second is the $90-10$ wage ratio, which is the ratio of gross earnings received by a worker at the 90th earnings percentile to that received by a worker at the $10^{\text {th }}$ earnings percentile. This is

100 Alvaredo et al. 2016. 
taken from the OECD Labour Force Statistics. ${ }^{101}$ Both our income inequality measures are before taxes and transfers (i.e. prior to government redistribution), which is appropriate for a study looking at the effects of the knowledge economy and labour market institutions on income inequality - i.e. we focus on distribution rather than redistribution.

The main reason we choose these two measures of income inequality is because they most closely match the theoretical channels identified in the literature review. Acemoglu and Pischke's theoretical models focus on the wage differential between skilled and unskilled labour and the empirical analyses in their work commonly utilize the 90-10 wage ratio to test their theories. ${ }^{102}$ The literature also shows that inequality at the very top of the income distribution is heavily influenced by the compensation of entrepreneurs, top managers, and CEOs. ${ }^{103}$ The top $1 \%$ income share is the most accurate inequality measure available for capturing the earnings of the most affluent people in society. It is calculated using tax returns, and because it avoids top coding, it captures income growth at the very top of the income distribution much better than traditional measures based on household surveys. ${ }^{104}$ In addition to theoretical considerations, these measures have superior data availability over other measures of income inequality, especially over time, which is crucial for panel data analysis. We also want our results to contribute to the wider empirical literature on the determinants of income inequality in the advanced democracies, where the $90-10$ wage ratio ${ }^{105}$ and the income share of the $1 \%^{106}$ are two of the most frequently used measures of inequality.

\footnotetext{
101 Brady, Huber, and Stephens 2014.

102 See, for example, Acemoglu 2003; Pischke 2005.

103 Piketty and Saez 2003; Alvaredo et al. 2013; Mankiw 2013; Kaplan and Rauh 2013.

104 Atkinson, Piketty, and Saez 2011.

105 Wallerstein 1999; Rueda and Pontusson 2000; Pontusson, Rueda, and Way 2002; Acemoglu 2003; Pischke 2005; Koeniger, Leonardi, and Nunziata 2007; Brady and Leicht 2008; Checchi and García-Peñalosa 2008. 106 Roine, Vlachos, and Waldenström 2009; Scheve and Stasavage 2009; Atkinson, Piketty, and Saez 2011; Alvaredo et al. 2013; Neal 2013; Piketty 2014; Huber, Huo, and Stephens 2017.
} 
The data availability, and therefore the samples, vary slightly for the two measures. The sample for the regression models using the top $1 \%$ income share covers 15 countries (no data is available from the World Wealth and Income Database for Austria, Belgium or Greece) and 541 country-year observations. The sample for the regression models using the $90-10$ wage ratio covers all 18 countries, but as this measure typically has shorter time series, the sample only has 322 country-year observations. Full details of the country-year coverage for our dependent variables are shown in Table A1 in the Appendix.

\section{KEY INDEPENDENT VARIABLES}

The measure of the knowledge economy used in our study follows Anne Wren's definition of dynamic services, which combines the sectors that have seen the greatest diffusion of new information and communications technologies. ${ }^{107}$ Table 2 uses EUKLEMS data to show the average contribution to value added growth of ICT capital services across 16 sectors for 12 advanced democracies between 1983 and 2006. Three sectors stand out as having significantly higher ICT contributions than the others: post and telecommunications, financial intermediation (covering finance and insurance), and renting of machinery and equipment and other business activities (which is dominated by business services such as legal, technical, computer, and advertising services). Our measure of knowledge-intensive services adds up employment in these three sectors from the EU KLEMS Growth and Productivity Accounts and expresses it as a percentage of total employment. ${ }^{108}$ Data on knowledge intensiveemployment for the 18 countries in our sample is available from $1970-2007 .^{109}$

\footnotetext{
107 Wren 2013.

108 O'Mahony and Timmer 2009.

109 Unfortunately, data from the newer EUKLEMS database and the related World-Input Output Database cannot be combined with the historical EUKLEMS data to make a consistent series for knowledge employment running further than 2007. This is due to differences in sector classifications across the databases.
} 
Knowledge-intensive services have other characteristics that set them apart from the other service sectors. Wren finds that they typically have higher productivity growth and are more likely to be traded internationally. ${ }^{110}$ This is no coincidence. The ICT revolution has drastically reduced the cost of performing routine, programmable tasks, ${ }^{111}$ which has pushed up productivity in ICT-intensive sectors. ${ }^{112}$ It has also lowered many of the technical barriers to trade in services, because digitized information can be almost costlessly stored and transported across the globe. ${ }^{113}$

Previous studies that estimate the effects of the knowledge economy on income inequality have also constructed measures of knowledge employment from sectoral data. Daniela Rohrbach and Evelyn Huber, Jingjing Huo, and John Stephens sum employment in sectors they deem to be knowledge-intensive (using OECD STAN and EUKLEMS data respectively). ${ }^{114}$ These authors select different sectors. Rohrbach includes high-tech manufacturing industries in her definition, ${ }^{115}$ whereas Huber, Huo, and Stephens focus solely on services. ${ }^{116}$ Huber, Huo, and Stephens measure includes sectors that are traditionally dominated by government provision, such as public administration, health and education. ${ }^{117}$

\footnotetext{
110 Wren 2013.

111 Nordhaus 2007.

112 Dahl, Kongsted, and Sørensen 2011; Spiezia 2012; Stiroh 2002.

113 Choi 2010; Freund and Weinhold 2002.

114 Rohrbach 2009; Huber, Huo, and Stephens 2017.

115 Rohrbach 2009.

116 Huber, Huo, and Stephens 2017.

117 This is likely why Huber, Huo, and Stephens 2017 find a negative effect of knowledge employment on income inequality, which contrasts with other studies that estimate this relationship (Kwon and Roberts 2015; Kwon 2016; Rohrbach 2009), because the empirical literature suggests that greater public sector employment can reduce income inequality, especially in coordinated market economies (Pontusson 2005; Pontusson, Rueda, and Way 2002; Rueda and Pontusson 2000).
} 
TABLE 2

THE CONTRIBUTION OF ICT CAPITAL SERVICES TO VALUE ADDED GROWTH ACROSS SECTORS IN 12 ADVANCED DEMOCRACIES, 1983 - 2006

\begin{tabular}{|c|c|}
\hline Sector & $\begin{array}{l}\text { Average contribution of ICT } \\
\text { capital services to value added } \\
\text { growth (percentage points) }\end{array}$ \\
\hline Agriculture, hunting, forestry and fishing & 0.074 \\
\hline Mining and quarrying & 0.205 \\
\hline Manufacturing & 0.411 \\
\hline Electricity, gas and water supply & 0.401 \\
\hline Construction & 0.169 \\
\hline Wholesale and retail trade & 0.558 \\
\hline Hotels and restaurants & 0.269 \\
\hline Transport and storage & 0.487 \\
\hline Post and telecommunications & 1.739 \\
\hline Financial intermediation & 1.512 \\
\hline Real estate activities & 0.126 \\
\hline Renting of machinery and equipment and other business activities & 1.173 \\
\hline Public administration and defence; compulsory social security & 0.427 \\
\hline Education & 0.237 \\
\hline Health and social work & 0.226 \\
\hline Other community, social and personal services & 0.569 \\
\hline
\end{tabular}

Note: The advanced democracies included are Australia, Austria, Belgium, Denmark, Spain, Finland, France, Italy, Japan, the Netherlands, the United Kingdom and the United States.

Source: EU KLEMS Growth and Productivity Accounts: November 2009 Release, updated March 2011; O’Mahony and Timmer (2009).

We believe Wren's measure of the knowledge employment is superior to these alternative measures for three main reasons. ${ }^{118}$ First, the sectors picked out by Wren have seen dramatic employment expansion across the advanced democracies since the collapse of the Fordist system (see Figure 1). Second, the knowledge-intensive sectors are selected through a transparent data-driven procedure (see Table 2). Lastly, the theoretical and empirical

\footnotetext{
118 Wren 2013.
} 
literature summarised in the previous section identifies ICT as the central mechanism that connects the transition to the knowledge economy to changes in the income distribution. ${ }^{119}$

Another approach that has been taken in past empirical work is to construct a measure of knowledge employment based on occupations. Kwon and Roberts utilize International Labour Organization data to construct a measure of knowledge employment that comprises managers, professionals, technicians and associate professionals; ${ }^{120}$ occupations focusing on non-routine, cognitive tasks that require the type of high-level general skills that are strongly complementary to ICT. ${ }^{121}$ This measure is only available from 1980 , but as a robustness test for our main results, we also run our analysis using this alternative measure of knowledge employment (as outlined in the Section IV). ${ }^{122}$

The other key independent variables are the four measures of labour market institutions. We take the coordination of wage-setting and the adjusted bargaining (or union) coverage rate from the ICTWSS database. ${ }^{123}$ The former measures the degree of coordination of wage setting on a five-point scale running from firm-level bargaining through to formal or informal centralised bargaining that sets explicit minimum or maximum rates of wage growth. The latter measures the proportion of all employees with the right to bargaining that are covered by collective (wage) bargaining agreements. We collect data on trade union membership from joint database compiled by the OECD and Jelle Visser. ${ }^{124}$ Trade union density measures the proportion of employees that are members of trade unions. Finally, we use the OECD Labour Force Statistics measure of employment protection legislation for workers on permanent

\footnotetext{
119 Acemoglu and Autor 2011; Goos, Manning, and Salomons 2014; Michaels, Natraj, and Van Reenen 2014.

120 Kwon and Roberts 2015.

121 Acemoglu and Autor 2011.

122 The data for this measure was kindly shared by Roy Kwon.

123 Visser 2016.

124 Visser 2013.
} 
contracts, which is expressed on a 0-6 scale, with higher values indicating that workers are harder to dismiss.

\section{CONTROL VARIABLES}

In our models with controls, we include a selection of additional variables that have been found to be drivers of income inequality in the theoretical and empirical literature. The variables cover the broad areas of education, financialization, globalization, and the economy.

Goldin and Katz argue that the post-industrial era in the United States has been marked by both a rise in the demand for higher education and a slowdown in educational expansion. ${ }^{125}$ The excess demand for educated labour created by education losing the race against technology creates upward pressure on the wages of more educated workers. The Goldin-Katz hypothesis has been found to hold across the advanced democracies. ${ }^{126}$ We include education expenditure as a percentage of gross national income from The World Bank World Development Indicators to account for investment in human capital, and hence, increases in the supply of educated workers.

Many panel data studies find that higher levels of financialization are associated with greater income inequality in the advanced democracies. ${ }^{127}$ Finance is one of the sub-sectors within our measure of knowledge-intensive services. To ensure that financialization is not driving our main results, we therefore control for stock market capitalisation as a percentage of GDP (from Roine, Vlachos, and Waldenström) and private credit as a percentage of GDP (from the Financial Development and Structure Dataset). ${ }^{128}$ These measures control for aspects

\footnotetext{
125 Goldin and Katz 2008; Goldin and Katz 2007.

126 Huber and Stephens 2014.

127 Flaherty 2015; Godechot 2016; Kus 2012; Roberts and Kwon 2017.

128 Roine, Vlachos, and Waldenström 2009; Beck, Demirgüç-Kunt, and Levine 2009; Beck, Demirgüç-Kunt, and Levine 2000; Čihák et al. 2012.
} 
of the growth of the financial sector over the post-Fordist era that affect inequality through different channels to those hypothesised for the broader knowledge-intensive services sector (as set out in the literature review), such as the increased use of stock options in the compensation packages of top managers and CEOs and the dramatic rise in household borrowing. As an additional robustness test for our main results, we also re-run our analysis with the financial intermediation sector excluded from our measure of knowledge employment (as outlined in the Section IV).

Another secular trend that has taken place alongside the transition to the knowledge economy is globalization. Goods and capital markets have become considerably more integrated over time, which has had knock on effects for inequality. We control for two different aspects of globalization: outward investment flows and import competition from developing economies. Investment outflows are measured by outward foreign direct investment as a percentage of GDP. Alderson and Nielsen and Lee, Nielsen, and Alderson find that higher outward investment flows lead to greater income inequality. ${ }^{129}$ The inflow of imports from the global south into the advanced democracies has been one of the major features of the postindustrial era. We follow other studies and measure southern import penetration by the value of manufactured goods (SITC Rev 1. 5-8) imports from developing economies as a percentage of GDP (calculated using data from the UN COMTRADE database and the OECD National Accounts). ${ }^{130131}$

Lastly, we control for conditions in the labour market using the unemployment rate as a percentage of the civilian labour force (from the OECD Labour Force Statistics). ${ }^{132}$ We also

\footnotetext{
129 Alderson and Nielsen 2002; Lee, Nielsen, and Alderson 2007.

130 Kwon and Roberts 2015; Roberts and Kwon 2017; Kwon, Roberts, and Zingula 2017.

131 The data for this measure was kindly shared by Roy Kwon.

132 As in Huber and Stephens 2014.
} 
collected and tested a number of other potential control variables, including measures of human capital, partisanship, trade openness, and economic development, but as they were highly correlated with other explanatory variables in the dataset, they were dropped from the final specifications due to concerns about collinearity.

The summary statistics for the two dependent variables, the key independent variables and the control variables are shown in Table 3. The small amount of missing values across the dataset have been linearly interpolated. The correlation matrix is shown in the Appendix (Table A2), as is the complete list of variable definitions and sources (Table A3).

TABLE 3

SUMMARY STATISTICS

\begin{tabular}{llllll}
\hline Variable & Obs. & Mean & Std. Dev. & Min & Max \\
\hline Top 1\% income share & 541 & 0.09 & 0.03 & 0.04 & 0.20 \\
\hline $90-10$ wage ratio & 322 & 3.04 & 0.67 & 1.88 & 4.86 \\
\hline $\begin{array}{l}\text { Knowledge employment } \\
\text { \% of total employment) }\end{array}$ & 682 & 0.11 & 0.04 & 0.03 & 0.22 \\
\hline Wage coordination $(1-5$ scale) & 669 & 3.25 & 1.40 & 1.00 & 5.00 \\
\hline Union density (\%) & 659 & 40.41 & 19.71 & 7.55 & 83.86 \\
\hline EPL $(0-6$ scale) & 414 & 2.20 & 0.99 & 0.26 & 5.00 \\
\hline Bargaining coverage $(0-100)$ & 614 & 70.62 & 24.38 & 12.61 & 98.00 \\
\hline Education expenditure $(\%$ of GNI) & 684 & 4.63 & 1.32 & 1.00 & 8.29 \\
\hline $\begin{array}{l}\text { Stock market capitalization } \\
\text { (\% of GDP) }\end{array}$ & 525 & 0.49 & 0.41 & 0.00 & 2.70 \\
\hline Private credit (\% of GDP) & 682 & 74.80 & 38.22 & 16.93 & 192.82 \\
\hline $\begin{array}{l}\text { Outward FDI (\% of GDP) } \\
\text { Southern import penetration }\end{array}$ & 628 & 2.16 & 3.98 & -4.70 & 47.01 \\
\hline $\begin{array}{l}\% \text { of GDP) } \\
\text { Unemployment rate }\end{array}$ & 661 & 13.78 & 8.17 & 1.11 & 54.15 \\
\hline
\end{tabular}




\section{EMPIRICAL STRATEGY}

The data for our analysis is unbalanced time series cross-sectional (TSCS) data covering 18 OECD countries. We employ Prais-Winsten regressions as our empirical strategy, which have been widely used in the empirical literature investigating the determinants of inequality in advanced democracies. ${ }^{133}$ Prais-Winsten regressions are estimated using ordinary least squares (OLS) and include both panel corrected standard errors (PCSEs) and a correction for firstorder auto-regression. The approach helps mitigate the problems of serial correlation, groupwise heteroscedasticity and contemporaneous cross-sectional correlation that are common in regression analyses using TSCS data. ${ }^{134}$

Our empirical strategy has clear advantages over other widely used approaches. Beck and Katz use Monte Carlo experiments to show that for the types of TSCS data used in comparative politics, OLS models with panel corrected standard errors provide more accurate estimates of standard errors than feasible generalized least squares estimation, and entail little loss of efficiency. ${ }^{135}$ We deal with serial correlation by including a correction for first-order autocorrelation, which is preferable to the alternative approach of adding a lagged dependent variable, which would absorb much of substantively interesting variation in our TSCS data and risk biasing the coefficient estimates on our main independent variables. ${ }^{136}$

Given that our unit of analysis in our TSCS data is countries, we also include countryfixed effects in our regressions, which control for unobserved, time-invariant, country-specific

\footnotetext{
133 Huber, Huo, and Stephens 2017; Volscho and Kelly 2012; Kwon, Roberts, and Zingula 2017; Kwon and Roberts 2015.

134 Beck and Katz 1995; Beck and Katz 2011; Plümper, Troeger, and Manow 2005.

135 Beck and Katz 1995.

136 Huber, Huo, and Stephens 2017; Plümper, Troeger, and Manow 2005.
} 
factors that influence inequality. Country fixed effects help guard against omitted variable bias and are commonly employed in Prais-Winsten regression models. ${ }^{137}$

The equations estimated in the empirical analysis are:

$$
\begin{aligned}
& y_{i t}=\beta_{0}+\beta_{1} X_{i t}+\beta_{2} W_{i t}+\beta_{3} X_{i t} * W_{i t}+\delta_{i}+\varepsilon_{i t} \\
& y_{i t}=\beta_{0}+\beta_{1} X_{i t}+\beta_{2} W_{i t}+\beta_{3} X_{i t} * W_{i t}+\sum \beta_{k} Z_{i t k}+\delta_{i}+\varepsilon_{i t}
\end{aligned}
$$

In both sets of models, $y_{i t}$ refers to our measures in income inequality: the income share of the top $1 \%$ and the $90-10$ wage ratio. The main independent variables in the analysis are $X_{i t}$, the share of total employment in knowledge-intensive services, and $W_{i t}$, our measures of labour market institutions. The interaction of our main independent variables, $X_{i t} * W_{i t}$, is crucial for testing the main hypotheses of the paper. In order to make the regression coefficients more easily interpretable, we mean centre the knowledge employment measure in all regression models. This means that the coefficients on the labour market institutions, $\beta_{2}$, can be interpreted as the effect of the labour market institutions on income inequality when knowledge employment is at its average value in the sample. Our four labour market institutions are tested in separate regression models; all of which also include country-fixed effects, $\delta_{i}$, and an intercept term, $\beta_{0}$. The second set of models also include a vector of $k$ control variables, represented by $Z_{i t k}$.

For the reasons outlined, we believe our empirical strategy is the most appropriate for our TSCS data, but we make sure to check the robustness of our results to alternative specifications. We first re-run the analysis adding decade dummies, as well as testing fixed and random effects models. To assuage any concerns about potential endogeneity in our regressions, especially reverse causality, we then use three different approaches that have been widely

137 Huber, Huo, and Stephens 2017; Kwon, Roberts, and Zingula 2017. 
employed in the empirical literature on the determinants of income inequality: 1) lagging all the explanatory variables by one period; ${ }^{138} 2$ ) two stage least-squares using lagged values (first three lags) of our key independent variables (and their interaction) as instruments (IV 2SLS); ${ }^{139}$ and 3) Arellano-Bond dynamic panel estimators. ${ }^{140}$ The results of the alternative specifications are shown in Tables S1 to S6 in the online supplementary materials. ${ }^{141}$

We also check the robustness of the results to using alternative measures of knowledge employment and using a common sample for the inequality measures. Table S7 in the online supplementary materials shows the results when we drop the financial intermediation sector from our measure of knowledge employment (to help allay any fears financialization is driving the main results). ${ }^{142}$ Table S8 shows the results when we use Kwon and Roberts' alternative, occupations-based measure of knowledge employment (to check the results are not specific to the measure of knowledge employment used). ${ }^{143144}$ Lastly, Table S9 shows the results when we restrict the sample to only the 303 country-years where data is available for both our measures of inequality. ${ }^{145}$

\section{RESULTS}

The results for the top 1\% income share are shown in Table 4 . Models 1 to 4 show the results from the baseline regressions, which simply include our main independent variables and an

\footnotetext{
138 Checchi and García-Peñalosa 2008; Kwon and Roberts 2015; Kwon, Roberts, and Zingula 2017.

139 In their study on inequality and labour market institutions, Jaumotte and Buitron 2015 instrument union density with lagged values of union density (first three lags). Li, Squire, and Zou 1998 is another example of an empirical study on inequality that uses lagged values of potential endogenous predictors as instruments. 140 Scheve and Stasavage 2009; Flaherty 2015.

141 Hope and Martelli 2018b.

142 Hope and Martelli 2018b.

143 Hope and Martelli 2018b.

144 Kwon and Roberts 2015

145 Hope and Martelli 2018b.
} 
interaction term, as well as country-fixed effects. In all four models, knowledge employment is positively associated with the income share of the top $1 \%$ and significant at the $99 \%$ level. The interaction effects between knowledge employment and the four labour market institutions are all negative, but the effects are only statistically significant for wage coordination, employment protection legislation, and bargaining coverage (and not union density). The baseline results tentatively support the hypothesis that the presence of strong labour market institutions reduces the effect of the transition to the knowledge economy on top incomes shares.

Models 5 to 8 in Table 4 introduce a full set of control variables. These models take account of other important drivers of inequality, covering education, financialization, globalization, and the economy. The results show that the effects of the expansion of knowledge employment on the income share of the top $1 \%$ is conditional on the strength of labour market institutions. The interaction effects for all the labour market institutions aside from union density are significant, negative, and of a similar magnitude to the baseline regressions. Only one of the control variables - stock market capitalisation - is statistically significant across all of the models. We find that it is positively associated with top income shares.

The main effects on the labour market institutions are negative (and mostly statistically significant) across all eight models, which suggests that labour market institutions exert a negative effect on the top $1 \%$ income share at the average level of knowledge employment in the sample. This fits with the previous empirical literature on the role of labour market institutions in restraining the income growth of the most affluent households. ${ }^{146}$

The results in Table 5 show the same eight regression models, but with the $90-10$ wage ratio as the dependent variable. The same patterns emerge for the main independent variables. In all eight regression models, knowledge employment is positively associated with the $90-10$

146 Huber, Huo, and Stephens 2017; Jaumotte and Buitron 2015. 
wage ratio and highly statistically significant. The interaction effects are also negative and significant in the baseline models and the models with controls for all four of the labour market institutions. Hence, while higher union density was not found to mitigate the effects of the knowledge economy on top incomes shares, it is found to moderate the effects on the wider income distribution. From Models 5 to 8 in Table 5, we can see that none of our control variables exert consistent statistically significant effects on the $90-10$ wage ratio.

Turning to the main effects of labour market institutions on the 90-10 wage ratio, we can see that they are mainly statistically insignificant. This does not necessarily undermine previous empirical studies that find a negative effect of labour market institutions on the 90 10 wage ratio, ${ }^{147}$ but it does suggest that the effects of labour market institutions operate through a channel that differs from those identified in previous studies. Our results suggest the most salient effects of labour market institutions on earnings inequality occur through their ability to alleviate the inequality-enhancing effects of the transition to knowledge economy.

147 Wallerstein 1999; Koeniger, Leonardi, and Nunziata 2007. 
TABLE 4

KNOWLEDGE EMPLOYMENT, LABOUR MARKET INSTITUTIONS, AND THE INCOME SHARE OF THE TOP 1\% (PRAIS-WINSTEN REGRESSIONS)

\begin{tabular}{|c|c|c|c|c|c|c|c|c|}
\hline & (1) & $(2)$ & (3) & (4) & $(5)$ & (6) & $(7)$ & $(8)$ \\
\hline Knowledge employment & $\begin{array}{c}0.525^{* * *} \\
(0.072)\end{array}$ & $\begin{array}{c}0.271^{* * *} \\
(0.080)\end{array}$ & $\begin{array}{c}1.063^{* * *} \\
(0.142)\end{array}$ & $\begin{array}{c}0.607^{* * *} \\
(0.160)\end{array}$ & $\begin{array}{c}0.452^{* * *} \\
(0.067)\end{array}$ & $\begin{array}{c}0.154^{* *} \\
(0.074)\end{array}$ & $\begin{array}{c}0.746^{* * *} \\
(0.131)\end{array}$ & $\begin{array}{c}0.783^{* * *} \\
(0.136)\end{array}$ \\
\hline Wage coordination & $\begin{array}{c}-0.001^{* *} \\
(0.000)\end{array}$ & & & & $\begin{array}{c}-0.001^{* * *} \\
(0.000)\end{array}$ & & & \\
\hline Union density & & $\begin{array}{c}-0.001^{* * *} \\
(0.000)\end{array}$ & & & & $\begin{array}{c}-0.001^{* * *} \\
(0.000)\end{array}$ & & \\
\hline EPL & & & $\begin{array}{c}-0.007^{*} \\
(0.004)\end{array}$ & & & & $\begin{array}{l}-0.003 \\
(0.003)\end{array}$ & \\
\hline Bargaining coverage & & & & $\begin{array}{l}-0.000 \\
(0.000)\end{array}$ & & & & $\begin{array}{l}-0.000 \\
(0.000)\end{array}$ \\
\hline $\begin{array}{l}\text { Wage coordination * } \\
\text { Knowledge employment }\end{array}$ & $\begin{array}{c}-0.059^{* * *} \\
(0.014)\end{array}$ & & & & $\begin{array}{c}-0.078^{* * *} \\
(0.015)\end{array}$ & & & \\
\hline $\begin{array}{l}\text { Union density }{ }^{*} \\
\text { Knowledge employment }\end{array}$ & & $\begin{array}{l}-0.002 \\
(0.002)\end{array}$ & & & & $\begin{array}{l}-0.001 \\
(0.001)\end{array}$ & & \\
\hline $\begin{array}{l}\text { EPL * } \\
\text { Knowledge employment }\end{array}$ & & & $\begin{array}{c}-0.207^{* * *} \\
(0.045)\end{array}$ & & & & $\begin{array}{c}-0.180^{* * *} \\
(0.040)\end{array}$ & \\
\hline $\begin{array}{l}\text { Bargaining coverage } * \\
\text { Knowledge employment }\end{array}$ & & & & $\begin{array}{c}-0.004^{* *} \\
(0.002)\end{array}$ & & & & $\begin{array}{c}-0.008^{* * *} \\
(0.002)\end{array}$ \\
\hline Education expenditure & & & & & $\begin{array}{c}0.000 \\
(0.001)\end{array}$ & $\begin{array}{l}-0.000 \\
(0.001)\end{array}$ & $\begin{array}{l}0.002^{* *} \\
(0.001)\end{array}$ & $\begin{array}{c}0.001 \\
(0.001)\end{array}$ \\
\hline Stock market capitalization & & & & & $\begin{array}{c}0.015^{* * *} \\
(0.003)\end{array}$ & $\begin{array}{c}0.015^{* * *} \\
(0.003)\end{array}$ & $\begin{array}{c}0.018^{* * *} \\
(0.003)\end{array}$ & $\begin{array}{c}0.016^{* * *} \\
(0.003)\end{array}$ \\
\hline Private credit & & & & & $\begin{array}{c}0.000 \\
(0.000)\end{array}$ & $\begin{array}{c}0.000 \\
(0.000)\end{array}$ & $\begin{array}{c}0.000 \\
(0.000)\end{array}$ & $\begin{array}{l}-0.000 \\
(0.000)\end{array}$ \\
\hline Outward FDI & & & & & $\begin{array}{l}-0.000 \\
(0.000)\end{array}$ & $\begin{array}{l}-0.000 \\
(0.000)\end{array}$ & $\begin{array}{l}-0.000 \\
(0.000)\end{array}$ & $\begin{array}{l}-0.000 \\
(0.000)\end{array}$ \\
\hline Southern import penetration & & & & & $\begin{array}{l}-0.000 \\
(0.000)\end{array}$ & $\begin{array}{c}0.000 \\
(0.000)\end{array}$ & $\begin{array}{c}0.000 \\
(0.000)\end{array}$ & $\begin{array}{l}-0.000 \\
(0.000)\end{array}$ \\
\hline Unemployment & & & & & $\begin{array}{c}-0.001^{* * *} \\
(0.000)\end{array}$ & $\begin{array}{l}-0.000 \\
(0.000)\end{array}$ & $\begin{array}{l}-0.000 \\
(0.000)\end{array}$ & $\begin{array}{c}-0.001^{* *} \\
(0.000)\end{array}$ \\
\hline Constant & $\begin{array}{c}0.103^{* * *} \\
(0.006)\end{array}$ & $\begin{array}{c}0.114^{* * *} \\
(0.007)\end{array}$ & $\begin{array}{c}0.098^{* * *} \\
(0.010)\end{array}$ & $\begin{array}{c}0.101^{* * *} \\
(0.014)\end{array}$ & $\begin{array}{c}0.098^{* * *} \\
(0.011)\end{array}$ & (omitted) & (omitted) & $\begin{array}{c}0.099^{* * *} \\
(0.013)\end{array}$ \\
\hline Observations & 538 & 538 & 342 & 503 & 459 & 459 & 300 & 444 \\
\hline $\mathrm{R}^{2}$ & 0.573 & 0.570 & 0.694 & 0.551 & 0.706 & 0.677 & 0.830 & 0.698 \\
\hline Countries & 15 & 15 & 15 & 15 & 15 & 15 & 15 & 15 \\
\hline
\end{tabular}

Note: Prais-Winsten regressions (panel-corrected standard errors and ar(1) corrections) with country fixed effects in all models. Unbalanced panel using data from 1970-2007. Pairwise option used to compute the covariance matrix. Knowledge employment is mean centred and comprises three sectors: post and telecommunications; financial intermediation; and renting of machinery and equipment and other business activities. ${ }^{*} \mathrm{P}<0.1,{ }^{* *} \mathrm{P}<0.05$ and ${ }^{* * *} \mathrm{P}<0.01$. 
TABLE 5

KNOWLEDGE EMPLOYMENT, LABOUR MARKET INSTITUTIONS, AND THE 90-10 WAGE RATIO (PRAIS-WINSTEN REGRESSIONS)

\begin{tabular}{|c|c|c|c|c|c|c|c|c|}
\hline & $(1)$ & $(2)$ & $(3)$ & $(4)$ & $(5)$ & $(6)$ & $(7)$ & $(8)$ \\
\hline Knowledge employment & $\begin{array}{l}7.935^{* * *} \\
(0.912)\end{array}$ & $\begin{array}{c}4.671^{* * *} \\
(1.410)\end{array}$ & $\begin{array}{c}8.465^{* * *} \\
(2.139)\end{array}$ & $\begin{array}{c}7.694^{* * *} \\
(1.466)\end{array}$ & $\begin{array}{l}7.779 * * * \\
(1.187)\end{array}$ & $\begin{array}{c}5.950^{* * *} \\
(1.669)\end{array}$ & $\begin{array}{l}7.176^{* * *} \\
(2.255)\end{array}$ & $\begin{array}{c}8.818^{* * *} \\
(1.638)\end{array}$ \\
\hline Wage coordination & $\begin{array}{l}-0.009 \\
(0.008)\end{array}$ & & & & $\begin{array}{l}-0.003 \\
(0.009)\end{array}$ & & & \\
\hline Union density & & $\begin{array}{c}-0.007^{* *} \\
(0.003)\end{array}$ & & & & $\begin{array}{c}0.000 \\
(0.004)\end{array}$ & & \\
\hline EPL & & & $\begin{array}{l}-0.032 \\
(0.092)\end{array}$ & & & & $\begin{array}{c}0.067 \\
(0.086)\end{array}$ & \\
\hline Bargaining coverage & & & & $\begin{array}{l}-0.000 \\
(0.002)\end{array}$ & & & & $\begin{array}{c}0.001 \\
(0.002)\end{array}$ \\
\hline $\begin{array}{l}\text { Wage coordination } * \\
\text { Knowledge employment }\end{array}$ & $\begin{array}{c}-1.576^{* * *} \\
(0.249)\end{array}$ & & & & $\begin{array}{c}-1.653^{* * *} \\
(0.289)\end{array}$ & & & \\
\hline $\begin{array}{l}\text { Union density }{ }^{*} \\
\text { Knowledge employment }\end{array}$ & & $\begin{array}{c}-0.058^{* *} \\
(0.022)\end{array}$ & & & & $\begin{array}{c}-0.075^{* * *} \\
(0.024)\end{array}$ & & \\
\hline $\begin{array}{l}\mathrm{EPL}^{*} \\
\text { Knowledge employment }\end{array}$ & & & $\begin{array}{c}-2.675^{* * *} \\
(0.892)\end{array}$ & & & & $\begin{array}{c}-2.366^{* * *} \\
(0.891)\end{array}$ & \\
\hline $\begin{array}{l}\text { Bargaining coverage } * \\
\text { Knowledge employment }\end{array}$ & & & & $\begin{array}{c}-0.070^{* * *} \\
(0.020)\end{array}$ & & & & $\begin{array}{c}-0.083^{* * *} \\
(0.019)\end{array}$ \\
\hline Education expenditure & & & & & $\begin{array}{l}-0.005 \\
(0.014)\end{array}$ & $\begin{array}{l}-0.004 \\
(0.015)\end{array}$ & $\begin{array}{l}0.031^{* *} \\
(0.014)\end{array}$ & $\begin{array}{l}-0.001 \\
(0.013)\end{array}$ \\
\hline Stock market capitalization & & & & & $\begin{array}{l}0.052^{*} \\
(0.029)\end{array}$ & $\begin{array}{l}0.054^{*} \\
(0.029)\end{array}$ & $\begin{array}{c}0.017 \\
(0.026)\end{array}$ & $\begin{array}{c}0.044 \\
(0.028)\end{array}$ \\
\hline Private credit & & & & & $\begin{array}{l}-0.000 \\
(0.000)\end{array}$ & $\begin{array}{c}0.000 \\
(0.001)\end{array}$ & $\begin{array}{c}0.000 \\
(0.000)\end{array}$ & $\begin{array}{l}-0.000 \\
(0.001)\end{array}$ \\
\hline Outward FDI & & & & & $\begin{array}{l}-0.000 \\
(0.001)\end{array}$ & $\begin{array}{l}-0.000 \\
(0.001)\end{array}$ & $\begin{array}{c}0.000 \\
(0.001)\end{array}$ & $\begin{array}{c}0.000 \\
(0.001)\end{array}$ \\
\hline Southern import penetration & & & & & $\begin{array}{c}0.001 \\
(0.004)\end{array}$ & $\begin{array}{c}0.003 \\
(0.004)\end{array}$ & $\begin{array}{l}0.006^{*} \\
(0.004)\end{array}$ & $\begin{array}{c}-0.001 \\
(0.003)\end{array}$ \\
\hline Unemployment & & & & & $\begin{array}{l}-0.003 \\
(0.005)\end{array}$ & $\begin{array}{c}-0.003 \\
(0.006)\end{array}$ & $\begin{array}{l}-0.004 \\
(0.005)\end{array}$ & $\begin{array}{c}-0.012^{* * *} \\
(0.004)\end{array}$ \\
\hline Constant & $\begin{array}{c}3.543^{* * *} \\
(0.056)\end{array}$ & $\begin{array}{c}3.623^{* * *} \\
(0.068)\end{array}$ & $\begin{array}{c}4.489^{* * *} \\
(0.404)\end{array}$ & $\begin{array}{c}2.709^{* * *} \\
(0.183)\end{array}$ & (omitted) & $\begin{array}{c}2.462^{* * *} \\
(0.297)\end{array}$ & $\begin{array}{c}3.824^{* * *} \\
(0.413)\end{array}$ & $\begin{array}{c}2.361^{* * *} \\
(0.282)\end{array}$ \\
\hline Observations & 320 & 320 & 255 & 314 & 275 & 275 & 216 & 270 \\
\hline $\mathrm{R}^{2}$ & 0.958 & 0.955 & 0.969 & 0.958 & 0.960 & 0.957 & 0.973 & 0.962 \\
\hline Countries & 18 & 18 & 18 & 18 & 16 & 16 & 16 & 16 \\
\hline
\end{tabular}

Note: Prais-Winsten regressions (panel-corrected standard errors and ar(1) corrections) with country fixed effects in all models. Unbalanced panel using data from 1970-2007. Pairwise option used to compute the covariance matrix. Knowledge employment is mean centred comprises three sectors: post and telecommunications; financial intermediation; and renting of machinery and equipment and other business activities. ${ }^{*} \mathrm{P}<0.1,{ }^{* *} \mathrm{P}<0.05$ and ${ }^{* * *} \mathrm{P}<0.01$. 
To get a clearer picture of the magnitude of the mitigating effects of labour market institutions, Figures 2 and 3 show the estimated effects of a one percentage point increase in employment in knowledge-intensive services on our two measures of inequality, when our labour market institutions are at the minimum and maximum values observed in the sample (see Table 3). We do not include union density in the figure for the top $1 \%$ income share as the interaction effect was not statistically significant (see Table 4). We can see from Figure 2 that for the income share of the top $1 \%$, an increase in knowledge employment is associated with an increase in inequality when wage coordination and collective bargaining coverage are very weak, and little or no effect when they are at their highest levels. Employment protection legislation exhibits a similar pattern, but the expansion of the knowledge economy is found to reduce inequality when employment protection is extremely strict. However, this finding should be taken with a pinch of salt, as the maximum value for EPL pertains only to Portugal between 1985 and 1989. Outside of those country-years, EPL is rarely above 3 in our sample. At 3, the estimated effect of a one percentage point increase in knowledge employment on the top $1 \%$ income share would be small and positive, and hence, more in line with the results for wage coordination and bargaining coverage.

Similar patterns emerge for the $90-10$ wage ratio in Figure 3. The effect of the expansion of the knowledge economy on inequality is positive when labour market institutions are weak, but negligible (or negative) when they are strong. Again, the same caveat applies to the EPL findings. At EPL of 3, the effect on the 90-10 wage ratio of an expansion of knowledge employment is also small and positive. Overall, these marginal effects figures highlight the role that strong labour market institutions can have in mitigating the inequality associated with the transition to the knowledge economy. 


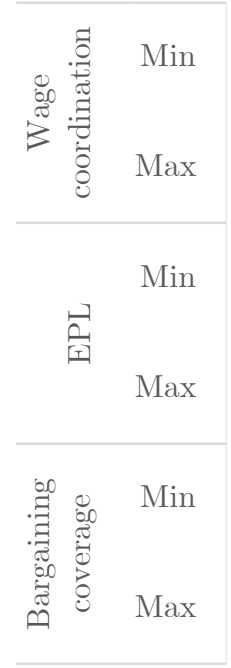

$-0.002$

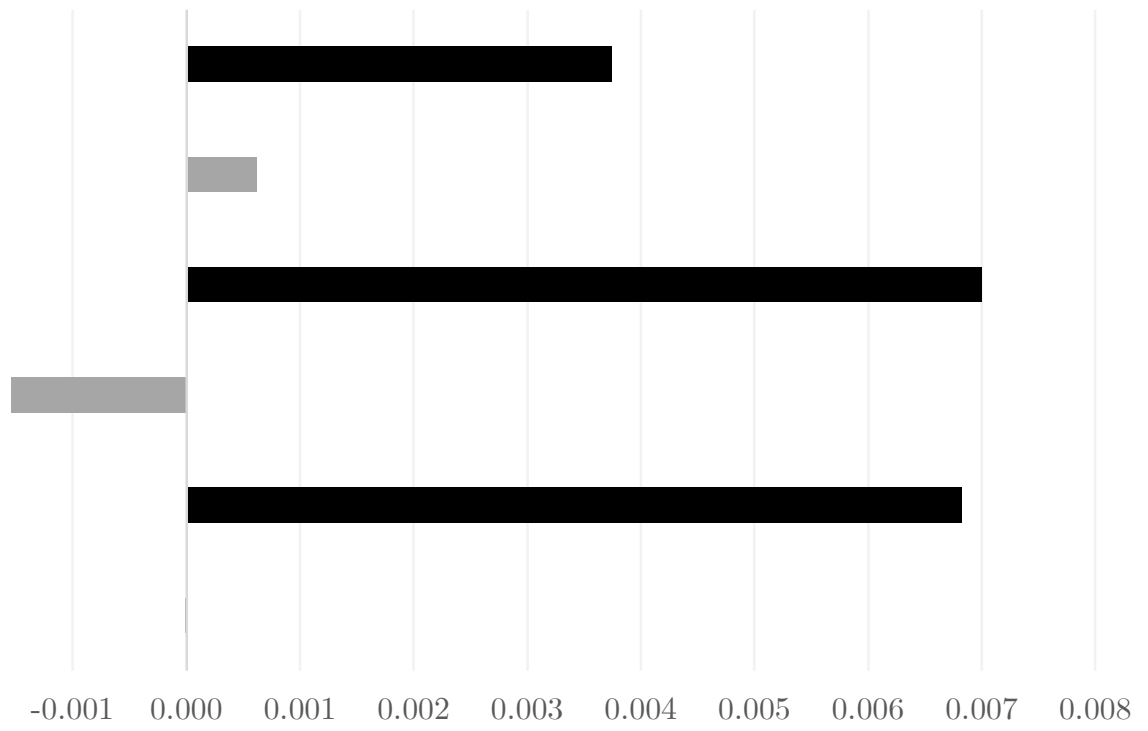

FIGURE 2

ESTIMATED EFFECT ON THE INCOME SHARE OF THE TOP 1\% OF A ONE PERCENTAGE POINT INCREASE IN THE SHARE OF KNOWLEDGE EMPLOYMENT

Source: Author's calculations; for data sources for the underlying regression analysis, see Table A3 in the Appendix.

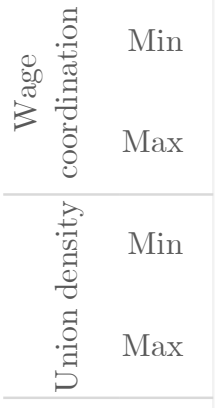

$$
\begin{aligned}
& \begin{array}{ll}
\text { 届 } & \\
& M a x
\end{array}
\end{aligned}
$$

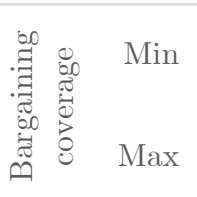

$-0.06$

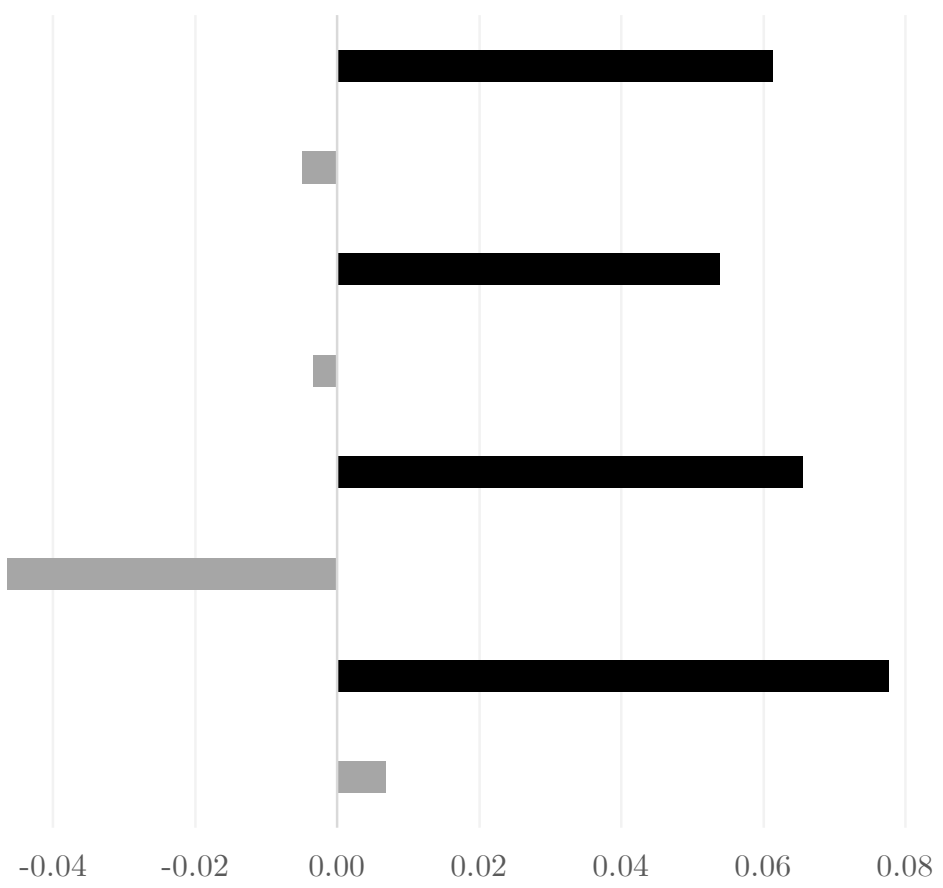

FIGURE 3

ESTIMATED EFFECT ON THE 90-10 WAGE RATIO OF A ONE PERCENTAGE POINT INCREASE IN THE SHARE OF KNOWLEDGE EMPLOYMENT

Source: Author's calculations; for data sources for the underlying regression analysis, see Table A3 in the Appendix. 
The results of the alternative specifications and robustness tests are shown in Tables S1 to S9 of the online supplementary materials. ${ }^{148}$ We can see that the main results of the analysis are largely unaffected by the empirical strategy chosen. The variables of theoretical interest exhibit the same relationships when we include decade dummies to our Prais-Winsten regressions (Table S1) or when we use fixed effects (Table S2) or random effects (Table S3) models. Similar to the main results, the only interaction effect that is not consistently statistically significant and negative is that between knowledge employment and union density in the top $1 \%$ income shares regressions.

The empirical strategies in Tables S4 to S6 of the online supplementary materials aim to assuage any fears that endogeneity is unduly influencing the results in the main analysis. ${ }^{149}$ The model with all the dependent variables lagged by one period and the IV 2SLS model strongly reinforce the results from our baseline Prais-Winsten regressions. The same key independent variables are statistically significant and the coefficients are of broadly the same magnitude (although the knowledge economy exerts a slightly larger effect on the 90-10 wage ratio in the instrumental variables models). In the Arellano-Bond dynamic panel estimation, the main results are substantively comparable, but less of the interaction effects are statistically significant. The interaction effect on wage coordination is negative and significant for both measures of inequality, as well as bargaining coverage for the top $1 \%$ income share and union density for the $90-10$ wage ratio.

Across all the alternative specifications stock market capitalization is found to exert a consistently statistically significant positive effect on the top $1 \%$ income share, just as in the

\footnotetext{
148 Hope and Martelli 2018b.

149 Hope and Martelli 2018b.
} 
main results, but unlike the main results, it is also positively associated with the $90-10$ wage ratio across many of the alternative specifications.

Tables S7 and S8 of the online supplementary materials show that the results are also robust to using different measures of the knowledge economy, which gives us confidence that our analysis is capturing the theoretical mechanisms we have identified, rather than any competing explanations, such as financialization. ${ }^{150}$ Lastly, Table S9 shows that the results are robust to using a common sample for our inequality measures. ${ }^{151}$

\section{DISCUSSION}

The study of the distribution of income, especially income inequality, is central to comparative political economy, and it has only risen in salience as labour market stratification has increased during the post-industrial era. ${ }^{152}$ Our findings make a valuable contribution to many of the key debates in comparative political economy on the knowledge economy, labour market institutions, and income inequality.

Baccaro and Howell's seminal work on liberalization argues that the industrial relations systems of the advanced capitalist economies have been transformed in a common neoliberal direction since the 1990s, which has undermined the egalitarian model of negotiated capitalism. ${ }^{153}$ While it is clear from our dataset that the post-industrial era has seen substantial liberalization in the industrial relations arena, our findings suggest that differences in the strength of labour market institutions across countries remain an important driver of crosscountry differences in income inequality.

\footnotetext{
150 Hope and Martelli 2018b.

151 Hope and Martelli 2018b.

152

Busemeyer and Iversen 2011.

153 Baccaro and Howell 2011; Baccaro and Howell 2017.
} 
The results of our study also push back against Iversen and Soskice's claim that due to the lack of complementarities between low- and high-skilled workers in the knowledge economy, industrial relations systems are no longer important safeguards of wage solidarity. ${ }^{154}$ We find strong evidence that industrial relations continue to be important, but our results are in no way dependent on contemporary industrial relations systems being underpinned by the complementarities and coalitions of the Fordist era. Like Kathleen Thelen, we view industrial relations systems as dynamic and open to reformulation. She argues that it is precisely where industrial relations systems have adapted - in both form and function - to the challenges of the knowledge economy that they have been most able to uphold egalitarian outcomes. ${ }^{155}$ For example, Denmark has one of the lowest levels of inequality in the advanced democracies (see Figure S1 in the online supplementary materials), but their current model of 'supply-side' solidarity is a far cry from the wage levelling approaches that the Danish unions pursued in the Fordist era. The dominant interests in the union movement now stretch beyond traditional blue-collar workers to include the salaried employees of the knowledge-intensive service sectors and the unions push hard for both labour market flexibility and rights to education and training, as they prize equality of opportunity over equality of outcomes. ${ }^{156}$

A particularly consistent finding in our empirical analysis is that wage coordination can mitigate the effects of the transition to the knowledge economy on income inequality. On the surface, this may appear in conflict with recent contributions that point to wage coordination, and coordinated capitalism more generally, no longer necessarily being associated with greater equality across the workforce. ${ }^{157}$ These contributions tend to focus on the bottom half of the

\footnotetext{
154 Iversen and Soskice 2015.

155 Thelen 2014; Ibsen and Thelen 2017.

156 Ibsen and Thelen 2017.

157 Thelen 2012; Thelen 2014; Vlandas 2018.
} 
income distribution, however, so unlike our measures of inequality, do not take adequate account of the effects of wage coordination on restraining earnings higher up the income distribution. In addition, we find strong evidence that union density and bargaining coverage also dampen the inequality-inducing effects of the transition to the knowledge economy, especially for the 90-10 wage ratio, which chimes with the common argument in this strand of the literature that egalitarian outcomes in the knowledge economy are concentrated in countries with more inclusive and encompassing industrial relations systems (for a given level of wage coordination). ${ }^{158}$

The only interaction effect in our analysis that was not consistently statistically significant and negative was that between union density and knowledge employment in the top $1 \%$ income shares regressions. This finding does not contradict the existing empirical literature that finds that union density helps contain the rise of top incomes ${ }^{159}$ however, as the coefficient on union density itself is consistently statistically significant and negative across our regression models. Higher union density therefore directly reduces the top $1 \%$ income share rather than mitigating the effects of the transition to the knowledge economy (as the other labour market institutions do). This shows that the effect of unions on executive compensation stretches across the economy and is not confined to knowledge-intensive service sectors.

Looking beyond the key independent variables, only stock market capitalisation exhibited consistent, statistically significant effects across the alternative specifications in our analysis. This supports the voluminous empirical literature on the importance of financialization for income inequality. ${ }^{160}$ It also hints at the specific mechanisms that might be at work, such as the increasing use of stock options as CEO compensation over the post-Fordist period and the

\footnotetext{
158 Thelen 2012; Thelen 2014; Ibsen and Thelen 2017; Vlandas 2018.

159 Jaumotte and Buitron 2015; Huber, Huo, and Stephens 2017.

160 Kus 2012; Flaherty 2015; Darcillon 2016; Godechot 2016; Roberts and Kwon 2017.
} 
gains to management and owners (and the losses to rank-and-file production workers) from the shift to shareholder-value orientated models of corporate governance.

\section{CONCLUSION}

The ICT revolution and the transition to the knowledge economy in the advanced democracies has created winners and losers. Workers with university education and the most affluent households have reaped much of the gains, often at the expense of those workers lower down the income distribution with jobs that can be easily substituted by machines and computers. The dominant narrative in the emerging comparative political economy literature on the knowledge economy is that the complementarities between skilled and semi-skilled workers that underpinned industrial relations systems in the Fordist era have been so undermined by the ICT revolution that strong labour market institutions are no longer the main guarantor of wage solidarity across the labour force. ${ }^{161}$

Our empirical analysis of 18 advanced democracies between 1970 and 2007 challenges that argument by showing that the presence of strong labour market institutions played an important role in mitigating the upward pressure on income inequality from the transition to the knowledge economy. We find that the effects of expanding knowledge employment on both the income share of the top $1 \%$ and the $90-10$ wage ratio are moderated by more coordinated wage bargaining, stricter employment protection legislation, and higher bargaining coverage. Additionally, we find that union density mitigates the effects of the transition to the knowledge economy on the 90-10 wage ratio, but not on the top $1 \%$ income share. Our results complement the wider empirical literature that finds that industrial relations systems and the power of organized labour can limit wage dispersion across the workforce and constrain the income

161 Baccaro and Howell 2011; Baccaro and Howell 2017; Iversen and Soskice 2015. 
growth of the most affluent households in society. ${ }^{162}$ However, we go beyond the previous literature by showing that labour market institutions effects in the post-industrial era operated through their capacity to counteract the pressures on wage solidarity arising from the rapid expansion of knowledge-intensive service sectors.

The analysis presented in this paper has several important limitations that point to fruitful avenues for future work. The Prais-Winsten regression models pin down the importance of labour market institutions for mitigating the inequality effects of the transition to the knowledge economy, but have a limited amount to say about the underlying mechanisms. Our cross-country comparative analysis would therefore be nicely complemented by micro-level empirical analyses or qualitative case study analyses into how labour market institutions have interacted with the expansion of knowledge employment to ensure greater wage solidarity in Scandinavia and some parts of continental Europe than elsewhere. The extent to which producer groups have adapted their strategies and forms of coordination in the knowledge economy is also hard to ascertain from the high-level, national measures of labour market institutions used in this study, and requires further investigation. Lastly, the advanced democracies vary not only in their expansion of knowledge-intensive services, but also in other aspects of their economic structure, such as the prevalence of employment in low-skilled, interpersonal services and the extent to which they have been able to preserve traditional manufacturing jobs. It is a clear challenge for future CPE work on the knowledge economy to bring together insights on the distributive implications of the full spectrum of structural changes that have taken place since the 1970s, and to work towards a more unified conceptual

\footnotetext{
162 Wallerstein 1999; Pontusson, Rueda, and Way 2002; Koeniger, Leonardi, and Nunziata 2007; Jaumotte and Buitron 2015; Huber, Huo, and Stephens 2017.
} 
framework for analysing the effects of structural change on income inequality in the advanced democracies.

This paper makes an important contribution to the growing body of comparative work that looks at how national institutions can condition the effects of major economic changes on income inequality in advanced democracies. ${ }^{163}$ We provide evidence against the argument that labour market institutions are redundant in the knowledge economy; in fact, we find that they play a central role in alleviating the upward pressure on income inequality arising from the continued march of workers in advanced democracies into knowledge-intensive service sectors.

163 Thelen 2014; Iversen and Soskice 2015; Darcillon 2016; Ibsen and Thelen 2017; Roberts and Kwon 2017; Kwon, Roberts, and Zingula 2017. 


\section{REFERENCES}

Acemoglu, Daron. 2003. "Cross-Country Inequality Trends." The Economic Journal 113, no. 485: 121-49. doi: 10.1111/1468-0297.00100.

Acemoglu, Daron, and David Autor. 2011. "Skills, Tasks and Technologies: Implications for Employment and Earnings." In Orley Ashenfelter and David Card, eds. Handbook of Labor Economics, vol 4B Amsterdam: Elsevier. doi: 10.1016/S0169-7218(11)02410-5.

Acemoglu, Daron, and Jörn-Steffen Pischke. 1998. "Why Do Firms Train? Theory and Evidence." The Quarterly Journal of Economics 113, no. 1: 79-119. doi: $10.1162 / 003355398555531$.

. 1999a. "Beyond Becker: Training in Imperfect Labour Markets." The Economic Journal 109, no. 453: 112-42. doi: 10.1111/1468-0297.00405.

—. 1999b. "The Structure of Wages and Investment in General Training." Journal of Political Economy 107, no. 3: 539-72. doi: 10.1086/250071.

Ahlquist, John S. 2017. "Labor Unions, Political Representation, and Economic Inequality." Annual Review of Political Science 20, no. 1: 409-32. doi: 10.1146/annurev-polisci-051215023225 .

Alderson, Arthur S., and François Nielsen. 2002. "Globalization and the Great U-Turn: Income Inequality Trends in 16 OECD Countries." American Journal of Sociology 107, no. 5: 1244-99. doi: 10.1086/341329.

Alvaredo, Facundo, Anthony B Atkinson, Thomas Piketty, and Emmanuel Saez. 2013. "The Top 1 Percent in International and Historical Perspective." Journal of Economic 
Perspectives 27, no. 3: 3-20. doi: 10.1257/jep.27.3.3.

Alvaredo, Facundo, Anthony B Atkinson, Thomas Piketty, Emmanuel Saez, and Gabriel Zucman. 2016. "World Wealth and Income Database." At https://wid.world/.

Arestis, Philip, and Eleni Paliginis. 1995. "Divergence and Peripheral Fordism in the European Union." Review of Social Economy 53, no. 2: 261-84. doi: 10.1080/00346769500000025.

Atkinson, Anthony B., Thomas Piketty, and Emmanuel Saez. 2011. "Top Incomes in the Long Run of History." Journal of Economic Literature 49, no. 1: 3-71. doi: 10.1257/jel.49.1.3.

Atkinson, Anthony B, and Thomas Piketty, eds. 2007. Top Incomes over the Twentieth Century: A Contrast between Continental European and English-Speaking Countries. Oxford: Oxford University Press.

Autor, David, and David Dorn. 2013. "The Growth of Low-Skill Service Jobs and the Polarization of the US Labor Market." The American Economic Review 103, no. 5 American Economic Association: 1553-97. doi: 10.1257/aer.103.5.1553.

Autor, David, David Dorn, Lawrence F Katz, Christina Patterson, and John Van Reenen. 2017a. "The Fall of the Labor Share and the Rise of Superstar Firms." NBER Working Paper Series no. No. 23396. doi: 10.3386/w23396.

2017b. "Concentrating on the Fall of the Labor Share." American Economic Review 107, no. 5: 180-85. doi: 10.1257/aer.p20171102.

Autor, David H., Lawrence F. Katz, and Melissa S. Kearney. 2006. "The Polarization of the U.S. Labor Market." American Economic Review 92, no. 2: 189-94. doi: $10.1257 / 000282806777212620$. 
Autor, David H, Frank Levy, and Richard J. Murnane. 2003. "The Skill Content of Recent Technological Change: An Empirical Exploration." The Quarterly Journal of Economics 118, no. 4: 1279-1333. doi: 10.1162/003355303322552801.

Baccaro, Lucio, and Chris Howell. 2011. "A Common Neoliberal Trajectory: The Transformation of Industrial Relations in Advanced Capitalism." Politics ES Society 39, no. 4: 521-63. doi: 10.1177/0032329211420082.

2017. Trajectories of Neoliberal Transformation: European Industrial Relations Since the 1970s. Cambridge: Cambridge University Press.

Barth, Erling, Alex Bryson, James C Davis, and Richard Freeman. 2016. "It's Where You Work: Increases in the Dispersion of Earnings across Establishments and Individuals in the United States." Journal of Labor Economics 34, no. S2: S67-97. doi: 10.1086/684045.

Beck, Nathaniel, and Jonathan N. Katz. 1995. "What to Do (and Not to Do) with Time-Series Cross-Section Data." The American Political Science Review 89, no. 3: 634-47. doi: $10.2307 / 2082979$.

Beck, Nathaniel, and Jonathan N Katz. 2011. "Modeling Dynamics in Time-Series-CrossSection Political Economy Data." Annual Review of Political Science 14, no. 1: 331-52. doi: 10.1146/annurev-polisci-071510-103222.

Beck, Thorsten, Asli Demirgüç-Kunt, and Ross Levine. 2000. "A New Database on the Structure and Development of the Financial Sector." The World Bank Economic Review 14, no. 3: 597-605. doi: 10.1093/wber/14.3.597.

2009. "Financial Institutions and Markets across Countries and over Time: Data and 
Analysis." World Bank Policy Research Working Paper No. 4943.

Blau, Francine D, and Lawrence M Kahn. 1996. "International Differences in Male Wage Inequality: Institutions versus Market Forces." Journal of Political Economy 104, no. 4: 791-837. doi: 10.1086/262043.

Boeri, Tito, Conde-Ruiz J Ignacio, and Galasso Vincenzo. 2012. "The Political Economy of Flexicurity." Journal of the European Economic Association 10, no. 4: 684-715. doi: 10.1111/j.1542-4774.2012.01065.x.

Bradley, David, Evelyne Huber, Stephanie Moller, François Nielsen, and John D. Stephens. 2003. "Distribution and Redistribution in Postindustrial Democracies." World Politics 55, no. 02: 193-228. doi: 10.1353/wp.2003.0009.

Brady, David, Regina S Baker, and Ryan Finnigan. 2013. "When Unionization Disappears: State-Level Unionization and Working Poverty in the United States." American Sociological Review 78, no. 5: 872-96. doi: 10.1177/0003122413501859.

Brady, David, Evelyne Huber, and John D. Stephens. 2014. "Comparative Welfare States Data Set." At http://www.lisdatacenter.org/resources/other-databases/.

Brady, David, and Kevin T Leicht. 2008. "Party to Inequality: Right Party Power and Income Inequality in Affluent Western Democracies." Research in Social Stratification and Mobility 26, no. 1: 77-106. doi: 10.1016/j.rssm.2007.01.001.

Brynjolfsson, Erik, and Andrew McAfee. 2014. The Second Machine Age: Work, Progress, and Prosperity in a Time of Brilliant Technologies. New York: W. W. Norton \& Company.

Bryson, Alex, Richard B. Freeman, Claudio Lucifora, Michele Pellizzari, and Virginie Pérotin. 
2012. "Paying for Perfomance: Incentive Pay Schemes and Employees' Financial Participation." CEP Discussion Paper No. 1112. At http://cep.lse.ac.uk/pubs/download/dp1112.pdf.

Busemeyer, Marius R., and Torben Iversen. 2011. "Collective Skill Systems, Wage Bargaining, and Labor Market Stratification." In Marius R. Busemeyer and Christine Trampusch, eds. The Political Economy of Collective Skill Formation Oxford: Oxford University Press.

Card, David. 2001. "The Effect of Unions on Wage Inequality in the U.S. Labor Market." ILR Review 54, no. 2: 296-315. doi: 10.1177/001979390105400206.

Card, David, Thomas Lemieux, and W Craig Riddell. 2004. "Unions and Wage Inequality." Journal of Labor Research 25, no. 4: 519-59. doi: 10.1007/s12122-004-1011-z.

Checchi, Daniele, and Cecilia García-Peñalosa. 2008. "Labour Market Institutions and Income Inequality." Economic Policy 23, no. 56: 602-49. doi: 10.1111/j.1468-0327.2008.00209.x.

Chen, Wen-hao, Michael Förster, and Ana Llena-Nozal. 2013. "Globalisation, Technological Progress and Changes in Regulations and Institutions - Which Impact on the Rise of Earnings Inequality in OECD Countries?" LIS Working Paper Series no. 597. At http://hdl.handle.net/10419/95521.

Choi, Changkyu. 2010. "The Effect of the Internet on Service Trade." Economics Letters 109, no. 2: 102-4. doi: 10.1016/j.econlet.2010.08.005.

Čihák, Martin, Asli Demirgüç-Kunt, Erik Feyen, and Ross Levine. 2012. "Benchmarking Financial Systems around the World." World Bank Policy Research Working Paper No. 
http://documents.worldbank.org/curated/en/868131468326381955/Benchmarkingfinancial-systems-around-the-world.

Dahl, Christian M, Hans Christian Kongsted, and Anders Sørensen. 2011. "ICT and Productivity Growth in the 1990s: Panel Data Evidence on Europe." Empirical Economics 40, no. 1: 141-64. doi: 10.1007/s00181-010-0421-4.

Darcillon, Thibault. 2015. "How Does Finance Affect Labor Market Institutions? An Empirical Analysis in 16 OECD Countries." Socio-Economic Review 13, no. 3: 477-504. doi: $10.1093 / \mathrm{ser} / \mathrm{mwu} 038$.

2016. "Do Interactions between Finance and Labour Market Institutions Affect the Income Distribution?" Labour 30, no. 3: 235-57. doi: 10.1111/labr.12070.

DiNardo, John, Kevin Hallock, and Jörn-Steffen Pischke. 1997. "Unions and Managerial Pay." National Bureau of Economic Research Working Paper Series. doi: 10.3386/w6318.

Emmenegger, Patrick, Silja Häusermann, Bruno Palier, and Martin Seeleib-Kaiser, eds. 2012. The Age of Dualization: The Changing Face of Inequality in Deindustrializing Societies. New York: Oxford University Press.

Flaherty, Eoin. 2015. "Top Incomes under Finance-Driven Capitalism, 1990-2010: Power Resources and Regulatory Orders." Socio-Economic Review 13, no. 3: 417-47. doi: $10.1093 / \mathrm{ser} / \mathrm{mwv} 011$.

Fligstein, Neil, and Taekjin Shin. 2007. "Shareholder Value and the Transformation of the U.S. Economy, 1984-2000." Sociological Forum 22, no. 4: 399-424. doi: 10.1111/j.1573- 
7861.2007.00044.x.

Freund, Caroline, and Diana Weinhold. 2002. "The Internet and International Trade in Services." The American Economic Review 92, no. 2: 236-40. doi: $10.1257 / 000282802320189320$.

Garicano, Luis, and Esteban Rossi-Hansberg. 2006. "Organization and Inequality in a Knowledge Economy." The Quarterly Journal of Economics 121, no. 4: 1383-1435. doi: 10.1093/qje/121.4.1383.

Godechot, Olivier. 2016. "Financialization Is Marketization! A Study of the Respective Impacts of Various Dimensions of Financialization on the Increase in Global Inequality." Sociological Science 3: 595-519. doi: 10.15195/v3.a22.

Golden, Miriam, and John Londregan. 2006. "Centralization of Bargaining and Wage Inequality: A Correction of Wallerstein." American Journal of Political Science 50, no. 1: 208-13. doi: 10.1111/j.1540-5907.2006.00179.x.

Goldin, Claudia, and Lawrence F. Katz. 2008. The Race Between Education and Technology. Cambridge: Harvard University Press.

Goldin, Claudia, and Lawrence F Katz. 2007. "Long-Run Changes in the Wage Structure: Narrowing, Widening, Polarizing." Brookings Papers on Economic Activity 2: 135-65.

Gomez, Rafael, and Konstantinos Tzioumis. 2006. "What Do Unions Do to Executive Compensation?" Centre for Economic Performance Discussion Paper No. 720. At http://eprints.lse.ac.uk/19865/.

Goos, Maarten, and Alan Manning. 2007. "Lousy and Lovely Jobs: The Rising Polarization of 
Work in Britain." Review of Economics and Statistics 89, no. 1: 118-33. doi: 10.1162/rest.89.1.118.

Goos, Maarten, Alan Manning, and Anna Salomons. 2009. "Job Polarization in Europe." American Economic Review: Papers $\&$ Proceedings 99, no. 2: 58-63. doi: 10.1257/aer.99.2.58.

2014. "Explaining Job Polarization: Routine-Biased Technological Change and Offshoring." American Economic Review 104, no. 8: 2509-26. doi: 10.1257/aer.104.8.2509.

Hacker, Jacob S, and Paul Pierson. 2010. "Winner-Take-All Politics: Public Policy, Political Organization, and the Precipitous Rise of Top Incomes in the United States." Politics $\mathbb{E}$ Society 38, no. 2: 152-204. doi: 10.1177/0032329210365042.

2011. Winner-Take-All Politics: How Washington Made the Rich Richer-And Turned Its Back on the Middle Class. Simon \& Schuster.

Hall, Peter A., and David Soskice. 2001. "An Introduction to Varieties of Capitalism." In Peter A. Hall and David Soskice, eds. Varieties of Capitalism: The Institutional Foundations of Comparative Advantage Oxford: Oxford University Press.

Hope, David, and Angelo Martelli. 2018a. "Replication Data for: The Transition to the Knowledge Economy, Labour Market Institutions, and Income Inequality in Advanced Democracies." Harvard Dataverse. doi: 10.7910/DVN/EUC80S.

. 2018b. "Supplementary Material for: The Transition to the Knowledge Economy, Labour Market Institutions, and Income Inequality in Advanced Democracies."

Hope, David, and David Soskice. 2016. "Growth Models, Varieties of Capitalism, and 
Macroeconomics." Politics \& Society 44, no. 2: 209-26. doi: 10.1177/0032329216638054.

Huber, Evelyne, Jingjing Huo, and John D. Stephens. 2017. "Power, Policy, and Top Income Shares." Socio-Economic Review 0, no. 0: 1-23. doi: 10.1093/ser/mwx027.

Huber, Evelyne, and John D Stephens. 2014. "Income Inequality and Redistribution in PostIndustrial Democracies: Demographic, Economic and Political Determinants." SocioEconomic Review 12: 245-67. doi: 10.1093/ser/mwu001.

Ibsen, Christian Lyhne, and Kathleen Thelen. 2017. "Diverging Solidarity: Labor Strategies in the New Knowldge Economy." World Politics 69, no. 3: 409-47. doi: 10.1017/S0043887117000077.

Iversen, Torben. 1999. Contested Economic Institutions: The Politics of Macroeconomics and Wage Bargaining in Advanced Democracies. New York: Cambridge University Press.

Iversen, Torben, and David Soskice. 2012. "Modern Capitalism and the Advanced Nation State: Understanding the Causes of the Crisis." In Nancy Bermeo and Jonas Pontusson, eds. Coping with Crisis: Government Reactions to the Great Recession New York: Russell Sage Foundation.

2015. "Democratic Limits to Redistribution: Inclusionary versus Exclusionary Coalitions in the Knowledge Economy." World Politics 67, no. 2: 185-225. doi: 10.1017/S0043887115000039.

Jacob Assa. 2012. "Financialization and Its Consequences: The OECD Experience." Finance Research 1, no. 1: 35-39. At http://researchpub.org/journal/fr/number/vol1-no1/vol1no1-4.pdf. 
Jaumotte, Florence, and Carolina Osorio Buitron. 2015. "Inequality and Labor Market Institutions." IMF Staff Discussion Note SDN/15/14. doi: 10.2139/ssrn.2678639.

Jaumotte, Florence, Subir Lall, and Chris Papageorgiou. 2013. "Rising Income Inequality: Technology, or Trade and Financial Globalization?" IMF Economic Review 61, no. 2: 271-309. doi: 10.1057/imfer.2013.7.

Kaplan, Steven N, and Joshua Rauh. 2013. "It's the Market: The Broad-Based Rise in the Return to Top Talent." The Journal of Economic Perspectives 27, no. 3: 35-55. doi: 10.1257/jep.27.3.35.

Katz, L. F., and D H. Autor. 1999. "Changes in the Wage Structure and Earnings Inequality." In O. Ashenfelter and D. E. Card, eds. Handbook of Labor Economics, Vol. 3A Amsterdam: Elsevier B.V.

Kenworthy, Lane, and Jonas Pontusson. 2005. "Rising Inequality and the Politics of Redistribution in Affluent Countries." Perspectives on Politics 3, no. 03: 449-71. doi: $10.1017 / \mathrm{S} 1537592705050292$.

Kim, Heekyung H., and Erik Brynjolfsson. 2009. "CEO Compensation and Information Technology." ISIC 2009 Proceedings 38. At http://aisel.aisnet.org/icis2009/38/.

Koeniger, Winfried, and Marco Leonardi. 2007. "Capital Deepening and Wage Differentials: Germany versus US." Economic Policy 22, no. 49: 72-116. doi: 10.1111/j.14680327.2007.00173.x.

Koeniger, Winfried, Marco Leonardi, and Luca Nunziata. 2007. "Labor Market Institutions and Wage Inequality." ILR Review 60, no. 3: 340-56. doi: 10.1177/001979390706000302. 
Kristal, Tali, and Yinon Cohen. 2007. "Decentralization of Collective Agreements and Rising Wage Inequality in Israel." Industrial Relations: A Journal of Economy and Society 46, no. 3: 613-35. doi: 10.1111/j.1468-232X.2007.00482.x.

. 2015. "What Do Computers Really Do? Computerization, Fading Pay-Setting Institutions and Rising Wage Inequality." Research in Social Stratification and Mobility 42: 33-47. doi: 10.1016/j.rssm.2015.07.001.

. 2017. "The Causes of Rising Wage Inequality: The Race between Institutions and Technology." Socio-Economic Review 15, no. 1: 187-212. doi: 10.1093/ser/mww006.

Krueger, Alan, and Jörn-Steffen Pischke. 1998. "Observations and Conjectures on the U.S. Employment Miracle." Third Public GAAC Symposium: Labor Markets in the USA and Germany German-American Academic Council, Bonn. doi: 10.3386/w6146.

Krugman, Paul. 1994. "Past and Prospective Causes of High Unemployment." Reducing Unemployment: Current Issues and Policy Options A Symposium Sponsored by the Federal Reserve Bank of Kansas City, August 25- 27, Jackson Hole, Wyoming. At https://www.kansascityfed.org/publicat/sympos/1994/s94krugm.pdf.

Kus, Basak. 2012. "Financialisation and Income Inequality in OECD Nations: 1995-2007." The Economic and Social Review 43, no. 4: 477-95. At https://www.esr.ie/article/view/34.

Kwon, R., and A. Roberts. 2015. "Financialization and Income Inequality in the New Economy." Sociology of Development 1, no. 4: 442-62. doi: 10.1525/sod.2015.1.4.442.

Kwon, R. 2014. "Employment Transitions and the Cycle of Income Inequality in Postindustrial Societies." International Journal of Comparative Sociology 55, no. 5: 404-28. doi: 
10.1177/0020715214561133.

Kwon, Roy. 2016. "A New Kuznetsian Dynamic: The Knowledge Economy and Income Inequality in the United States, 1917-2008." Sociological Quarterly 57, no. 1: 174-204. doi: $10.1111 /$ tsq. 12106 .

Kwon, Roy, Anthony Roberts, and Karissa Zingula. 2017. "Whither the Middle Class? Financialization, Labor Institutions, and the Gap Between Top- and Middle-Income Earners in Advanced Industrial Societies." Sociology of Development 3, no. 4: 377-402. doi: $10.1525 / \operatorname{sod} .2017 .3 .4 .377$.

Lee, Cheol-Sung, François Nielsen, and Arthur S Alderson. 2007. "Income Inequality, Global Economy and the State." Social Forces 86, no. 1: 77-111. doi: 10.1353/sof.2007.0102.

Lemieux, Thomas. 2011. "Wage Inequality: A Comparative Perspective." Australian Bulletin of Labour 37, no. 1: 2-32. At http://hdl.handle.net/2328/25989.

Lemieux, Thomas, W. Bentley MacLeod, and Daniel Parent. 2009. "Performance Pay and Wage Inequality." The Quarterly Journal of Economics 124, no. 1: 1-49. doi: 10.1093/qje/qjq008.

Li, Hongyi, Lyn Squire, and Heng-fu Zou. 1998. "Explaining International and Intertemporel Variations in Income Inequality." Economic Journal 108: 26-43. doi: 10.1111/14680297.00271.

Lin, Ken-Hou, and Donald Tomaskovic-Devey. 2013. "Financialization and U.S. Income Inequality, 1970-2008." American Journal of Sociology 118, no. 5: 1284-1329. doi: $10.1086 / 669499$. 
Lloyd, Caroline, Claudia Weinkopf, and Rosemary Batt. 2010. "Restructuring Customer Service: Labor Market Institutions and Call Center Workers In Europe and the United States." In J. Gautié and J. Schmitt, eds. Low-Wage Work in the Wealthy World New York: Russell Sage Foundation.

Mankiw, N. Gregory. 2013. "Defending the One Percent." Journal of Economic Perspectives 27, no. 3: 21-34. doi: 10.1257/jep.27.3.21.

Martelli, Angelo. 2017. "Essays on the Political Economy of Employment Polarization: Global Forces and Domestic Institutions." doi: 10.21953/lse.ka6x8cxiuycq.

Meyer, Brett. 2017. "Financialization, Technological Change, and Trade Union Decline." SocioEconomic Review: 1-26. doi: 10.1093/ser/mwx022.

Michaels, Guy, Ashwini Natraj, and John Van Reenen. 2014. "Has ICT Polarized Skill Demand? Evidence from Eleven Countries over Twenty-Five Years." Review of Economics and Statistics 96, no. 1: 60-77. doi: 10.1162/REST_a_00366.

Milanovic, Branko, and Lyn Squire. 2005. "Does Tariff Liberalization Increase Wage Inequality? Some Empirical Evidence." NBER Working Paper 11046. doi: $10.3386 /$ w11046.

Mosher, James S. 2007. "U.S. Wage Inequality, Technological Change, and Decline in Union Power." Politics and Society 35, no. 2: 225-64. doi: 10.1177/0032329207300394.

Murphy, Emily C, and Daniel Oesch. 2017. "Is Employment Polarisation Inevitable? Occupational Change in Ireland and Switzerland, 1970-2010." Work, Employment and Society. doi: 10.1177/0950017017738944. 
Murphy, Kevin J, and Ján Zábojník. 2004. "CEO Pay and Appointments: A Market-Based Explanation for Recent Trends." The American Economic Review 94, no. 2: 192-96. doi: $0.1257 / 0002828041302262$.

Neal, Timothy. 2013. "Using Panel Co-Integration Methods To Understand Rising Top Income Shares." Economic Record 88, no. 284: 83-98. doi: 10.1111/1475-4932.12018.

Nickell, Stephen, and Brian Bell. 1995. "The Collapse in Demand for the Unskilled and Unemployment Across the OECD." Oxford Review of Economic Policy 11, no. 1: 40-62. doi: 10.1093/oxrep/11.1.40.

—. 1996. "Changes in the Distribution of Wages and Unemployment in OECD Countries." American Economic Review, Papers and Proceedings 86, no. 2.

Nordhaus, William D. 2007. "Two Centuries of Productivity Growth in Computing." The Journal of Economic History 67, no. 1: 128-59. doi: 10.1017/S0022050707000058.

O’Mahony, Mary, and Marcel P Timmer. 2009. "Output, Input and Productivity Measures at the Industry Level: The EU KLEMS Database*." The Economic Journal 119, no. 538: F374--F403. doi: 10.1111/j.1468-0297.2009.02280.x.

OECD. 2011. Divided We Stand: Why Inequality Keeps Rising. Paris: OECD Publishing. doi: 10.1787/9789264119536-en.

. 2015. In It Together: Why Less Inequality Benefits All. Paris: OECD Publishing. doi: 10.1787/9789264235120-en.

Oesch, Daniel. 2013. Occupational Change in Europe: How Technology and Education Transform the Job Structure. Oxford University Press. 
. 2015. "Welfare Regimes and Change in the Employment Structure: Britain, Denmark and Germany since 1990." Journal of European Social Policy 25, no. 1: 94-110. doi: $10.1177 / 0958928714556972$.

Oesch, Daniel, and Jorge Rodríguez Menés. 2011. "Upgrading or Polarization? Occupational Change in Britain, Germany, Spain and Switzerland, 1990-2008." Socio-Economic Review 9, no. 3: 503-31. doi: 10.1093/ser/mwq029.

Palier, Bruno, and Kathleen Thelen. 2012. "Dualization and Institutional Complementarities: Industrial Relations, Labor Market, and Welfare State Changes in France and Germany." In Patrick Emmenegger, Silja Häusermann, Bruno Palier, and Martin Seeleib-Kaiser, eds. The Age of Dualization: The Changing Face of Inequality in Deindustrializing Societies New York: Oxford University Press.

Palley, Thomas I. 2013. "Financialization: What It Is and Why It Matters." In Thomas I Palley, ed. Financialization: The Economics of Finance Capital Domination London: Palgrave Macmillan UK. doi: 10.1057/9781137265821_2.

Philippon, Thomas, and Ariell Reshef. 2012. "Wages and Human Capital in the U.S. Financial Industry: 1909-2006." Quarterly Journal of Economics 127, no. 4 (November): 1551-1609. doi: 10.1093/qje/qjs030.Advance.

Piketty, Thomas. 2014. Capital in the Twenty-First Century. Cambridge, Massachusetts, and London, England: Harvard University Press.

Piketty, Thomas, and Emmanuel Saez. 2003. "Income Inequality in the United States, 19131998." The Quarterly Journal of Economics 118, no. 1: 1-41. doi: $10.1162 / 00335530360535135$. 
Pischke, Jörn-Steffen. 2005. "Labor Market Institutions, Wages, and Investment: Review and Implications." CESifo Economic Studies 51, no. 1: 47-75. doi: 10.1093/cesifo/51.1.47.

Plümper, Thomas, Vera E. Troeger, and Philip Manow. 2005. "Panel Data Analysis in Comparative Politics: Linking Method to Theory." European Journal of Political Research 44, no. 2: 327-54. doi: 10.1111/j.1475-6765.2005.00230.x.

Pontusson, Jonas. 2005. Inequality and Prosperity: Social Europe vs. Liberal America. Ithaca and London: The Century Foundation / Cornell University Press.

Pontusson, Jonas, David Rueda, and Christopher R Way. 2002. "Comparative Political Economy of Wage Distribution: The Role of Partisanship and Labour Market Institutions." British Journal of Political Science 32, no. 2: 281-308. doi: 10.1017/S000712340200011X.

Roberts, Anthony, and Roy Kwon. 2017. "Finance, Inequality and the Varieties of Capitalism in Post-Industrial Democracies." Socio-Economic Review 15, no. 3: 511-38. doi: $10.1093 / \mathrm{ser} / \mathrm{mwx} 021$.

Rohrbach, Daniela. 2009. "Sector Bias and Sector Dualism." International Journal of Comparative Sociology 50, no. 5-6: 510-36. doi: 10.1177/0020715209339885.

Roine, Jesper, Jonas Vlachos, and Daniel Waldenström. 2009. "The Long-Run Determinants of Inequality: What Can We Learn from Top Income Data?" Journal of Public Economics 93, no. 7: 974-88. doi: 10.1016/j.jpubeco.2009.04.003.

Rueda, David, and Jonas Pontusson. 2000. "Wage Inequality and Varieties of Capitalism." World Politics 52, no. 3: 350-83. doi: 10.1017/S0043887100016579. 
Scheve, Kenneth, and David Stasavage. 2009. "Institutions, Partisanship, and Inequality in the Long Run." World Politics 61, no. 2: 215-53. doi: 10.1017/S0043887109000094.

Schneider, Martin R, and Mihai Paunescu. 2012. "Changing Varieties of Capitalism and Revealed Comparative Advantages from 1990 to 2005: A Test of the Hall and Soskice Claims." Socio-Economic Review 10: 731-53. doi: 10.1093/ser/mwr038.

Shin, Taekjin. 2014. "Explaining Pay Disparities between Top Executives and Nonexecutive Employees: A Relative Bargaining Power Approach." Social Forces 92, no. 4: 1339-72. doi: $10.1093 /$ sf/sou004.

Song, Jae, David J Price, Fatih Guvenen, and Nicholas Bloom. 2015. "Firming Up Inequality." CEP Discussion Paper no. No. 1354. At http://cep.lse.ac.uk/pubs/download/dp1354.pdf.

Spiezia, Vincenzo. 2012. "ICT Investments and Productivity: Measuring the Contribution of ICTs to Growth." OECD Journal: Economic Studies 2012, no. 1: 199-211. doi: 10.1787/eco_studies-2012-5k8xdhj4tv0t.

Stiroh, Kevin J. 2002. "Information Technology and the U.S. Productivity Revival: What Do the Industry Data Say?" The American Economic Review 92, no. 5: 1559-76. doi: $10.1257 / 000282802762024638$.

Thelen, Kathleen. 2012. "Varieties of Capitalism: Trajectories of Liberalization and the New Politics of Social Solidarity." Annual Review of Political Science 15: 137-59. doi: 10.1146/annurev-polisci-070110-122959.

. 2014. Varieties of Liberalization and the New Politics of Social Solidarity. New York: Cambridge University Press. 
Thewissen, Stefan, Olaf van Vliet, and Chen Wang. 2018. "Taking the Sector Seriously: Data, Developments, and Drivers of Intrasectoral Earnings Inequality." Social Indicators Research 138, no. 3: 1023-48. doi: 10.1007/s11205-017-1677-2.

Tomaskovic-Devey, Donald, and Ken-Hou Lin. 2011. "Income Dynamics, Economic Rents, and the Financialization of the U.S. Economy." American Sociological Review 76, no. 4: 53859. doi: $10.1177 / 0003122411414827$.

Visser, J. 2013. ICTWSS Database Version 3.0. Amsterdam: Amsterdam Institute for Advanced Labour Studies AIAS (September 2016). At http://uva-aias.net/en/ictwss. 2016. ICTWSS Database Version 5.1. Amsterdam: Amsterdam Institute for Advanced Labour Studies AIAS. At http://uva-aias.net/en/ictwss.

Vlandas, Tim. 2018. "Coordination, Inclusiveness and Wage Inequality between Median- and Bottom-Income Workers." Comparative European Politics 16, no. 3: 482-510. doi: 10.1057/cep.2016.25.

Volscho, Thomas W., and Nathan J. Kelly. 2012. "The Rise of the Super-Rich." American Sociological Review 77, no. 5: 679-99. doi: 10.1177/0003122412458508.

Wallerstein, Michael. 1999. "Wage-Setting Institutions and Pay Inequality in Advanced Industrial Societies." American Journal of Political Science 43, no. 3: 649-80.

Western, Bruce, and Jake Rosenfeld. 2011. "Unions, Norms, and the Rise in U.S. Wage Inequality." American Sociological Review 76, no. 4: 513-37. doi: $10.1177 / 0003122411414817$.

Wolff, Edward N. 2006. "Skills, Computerization and Income Inequality in the Postwar U.S. 
Economy." In John Creedy and Guyonne Kalb, eds. Dynamics of Inequality and Poverty (Research on Economic Inequality, Volume 13) Research on Economic Inequality Emerald Group Publishing Limited. doi: 10.1016/S1049-2585(06)13009-4.

Wren, Anne. 2013. "Introduction: The Political Economy of Post-Industrial Societies." In Anne Wren, ed. The Political Economy of the Service Transition Oxford: Oxford University Press. 


\section{APPENDIX}

TABLE A1

COUNTRY-YEAR COVERAGE FOR THE DEPENDENT VARIABLES

\begin{tabular}{|c|c|c|}
\hline Country & Income share of the top $1 \%$ & $90-10$ wage ratio \\
\hline Australia & $1970-2007$ & $1975-2007$ \\
\hline Austria & - & $2004-2007$ \\
\hline Belgium & - & $1999-2007$ \\
\hline Canada & $1970-2007$ & $1997-2007$ \\
\hline Denmark & $1970-2007$ & $1996-2007$ \\
\hline Finland & $1970-2007$ & $1977-2007$ \\
\hline France & $1970-2007$ & $1995-2007$ \\
\hline Germany & $1971-2007$ & $1992-2007$ \\
\hline Greece & - & $2004-2007$ \\
\hline Ireland & $1975-2007$ & $1994-2007$ \\
\hline Italy & $1974-2007$ & $1986-2007$ \\
\hline Japan & $1970-2007$ & $1975-2007$ \\
\hline Netherlands & $1970-2007$ & $2002-2007$ \\
\hline Portugal & $1976-2005$ & $2004-2007$ \\
\hline Spain & $1981-2007$ & $2004-2007$ \\
\hline Sweden & $1970-2007$ & $1975-2007$ \\
\hline United Kingdom & $1970-2007$ & $1970-2007$ \\
\hline United States & $1970-2007$ & $1973-2007$ \\
\hline
\end{tabular}

TABLE A2

CORRELATION MATRIX

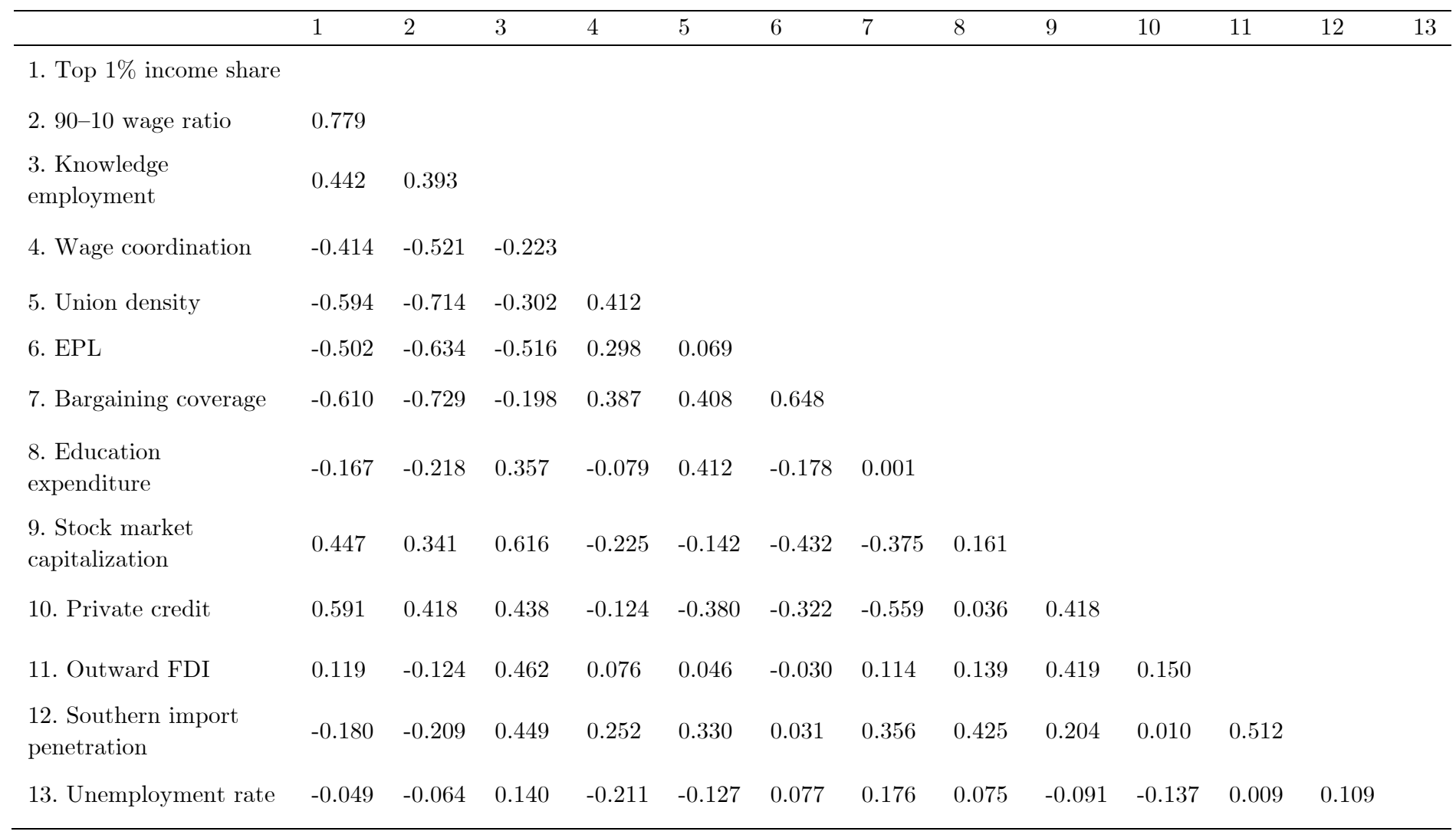


TABLE A3

VARIABLE DESCRIPTIONS AND SOURCES

\begin{tabular}{|c|c|}
\hline Variable & Variable description \\
\hline $\begin{array}{l}\text { Top } 1 \% \text { income } \\
\text { share }\end{array}$ & Top $1 \%$ income share, based on pre-tax incomes \\
\hline $90-10$ wage ratio & $\begin{array}{l}\text { Ratio of gross earnings received by a worker at } \\
\text { the } 90 \text { th earnings percentile to that received by a } \\
\text { worker at the } 10 \text { th percentile }\end{array}$ \\
\hline $\begin{array}{l}\text { Knowledge } \\
\text { employment } \\
\text { (\% of total } \\
\text { employment) }\end{array}$ & $\begin{array}{l}\text { Employment in dynamic services as a share of } \\
\text { total employment (using Wren's } 2013 \text { definition } \\
\text { of dynamic services) }\end{array}$ \\
\hline $\begin{array}{l}\text { Alternative } \\
\text { measure of } \\
\text { knowledge } \\
\text { employment }\end{array}$ & $\begin{array}{l}\text { Number of workers in the knowledge sector (as a } \\
\% \text { of total labour force). Kwon and Roberts' } \\
\text { (2015) measure combines managers, } \\
\text { professionals, technicians and associate } \\
\text { professionals (variable categorized using } 1988 \\
\text { version of ISCO) }\end{array}$ \\
\hline $\begin{array}{l}\text { Wage coordination } \\
(1-5 \text { scale })\end{array}$ & $\begin{array}{l}\text { Coordination of wage-setting } \\
\text { (1-5 scale) - a measure of the degree of } \\
\text { coordination, ranging from firm-level bargaining } \\
\text { (1) to fully centralized bargaining }(5)\end{array}$ \\
\hline
\end{tabular}

(1) to fully centralized bargaining (5)

Source

Alvaredo et al. (2016); World Wealth \& Income

Database (data accessed September 2017)

Brady, Huber and Stephens (2014); OECD Labour

Force Statistics (accessed 14 Jan 2013)

EU KLEMS Growth and Productivity Accounts: November 2009 Release, updated March 2011; O'Mahony and Timmer (2009)

International Labour Organization (data kindly provided by Roy Kwon; measure also used in Kwon and Roberts (2015))

J. Visser, ICTWSS Data base. version 5.1.

Amsterdam: Amsterdam Institute for Advanced

Labour Studies (AIAS), University of Amsterdam. September 2016

OECD and J. Visser, ICTWSS database

(Institutional Characteristics of Trade Unions, Wage

Setting, State Intervention and Social Pacts, 1960-

2010), version 3.0 (http://www.uva-aias.net/)

OECD Labour Force Statistics (data accessed June 2017)

and collective dismissals (regular contracts) scale) - higher values denote stricter regulation

Employees covered by collective (wage) bargaining agreements as a \% of all wage and

Bargaining coverage

$(0-100)$ salary earners in employment with the right to bargaining, expressed as percentage, adjusted for the possibility that some sectors or occupations are excluded from the right to bargain

$\begin{array}{ll}\text { Education } & \text { Adjusted savings: education expenditure } \\ \text { expenditure } & (\% \text { of GNI }) \\ (\% \text { of GNI }) & \end{array}$

Stock market capitalization (\% of GDP)

Stock market capitalization: market value of publicly listed stocks divided by GDP

Roine, Vlachos, and Waldenström (2009)
J. Visser, ICTWSS Data base. version 5.1.
Amsterdam: Amsterdam Institute for Advanced Labour Studies (AIAS), University of Amsterdam. September 2016.

World Development Indicators, The World Bank (data accessed September 2017) $\begin{array}{ll}\text { Private credit } & \text { Private credit by deposit money banks and other } \\ (\% \text { of GDP }) & \text { financial institutions (as a } \% \text { of GDP) }\end{array}$

Outward FDI

(\% of GDP)

Outward foreign direct investment (as a \% of GDP)

Southern import penetration (\% of GDP)

Unemployment rate
Southern import penetration: value of manufacturing imports from developing economies (SITC REV 1. 5-8) as a \% of GDP

Rate of unemployment as a \% of the civilian labour force
Financial Development and Structure Dataset (June 2017 version); Beck, Demirgüç-Kunt, and Levine (2000, 2009) Čihák et al. (2012)

United Nations Conference on Trade and Development (UNCTAD) Foreign Direct Investment Database (data accessed September 2017)

United Nations COMTRADE Database (data kindly provided by Roy Kwon; measure also used in Kwon and Roberts (2015))

OECD Labour Force Statistics (data accessed September 2017) 